\title{
USING G.I.S. PRODUCTS FOR ANALYSING THE POTENTIAL OF PRACTISING SUSTAINABLE TOURISM AND DEVELOPING ZECE HOTARE VILLAGE
}

\author{
Alina TODERAȘ \\ "Ferdinand I" Military Technical Academy, Bucharest, ROMANIA \\ alinatoderas1@gmail.com \\ DOI: http://doi.org/10.23740/TID120204
}

\begin{abstract}
Zece Hotare village (Bihor County, Romania) is part of the disadvantaged areas category, being a former mining village, due to the exploitation of bauxite and clay resources. Today, its socio-economic situation is precarious, the econom ic sector being poorly developed, and the population is constantly declining. At present, it is an agricultural and forestry village. One of the solutions that could lead to achieving a balance and improving the economic situation and maintaining the existing population in the village, would be to capitalize on local resources by practicing rural touris $\mathrm{m}$, in particular agritourism. Although recreational tourism is sometimes practised, agritourism is currently non-existent within the area. However, by practicing agritourism, the specific values, customs and traditions would be prom oted. This study aims to propose and analyse possible options for the development of rural tourism, mountain tourism, ecotourism, agritourism, and cycling tourism, as well as which activities should be undertaken to practise these forms of tourism and to attracting tourist flows towards Zece Hotare village. Some of the proposals for tourism development in Zece Hotare provided in the study are as follows: construction of boarding houses; presentations addressed to locals about what the practice of agritourism involves, in order to observe their degree of openness and availability to contribute to practicing this form of tourism as hosts; creating thematic paths for picking medicinal plants; creating a cycle tourist route that includes a tour of the hamlets in the village; building boutiques where locals can sell their products, such as honey, bakery products, woven and embroidered clothes, wooden objects, etc.; arranging places for camping, arranging places for leisure activities, and others.
\end{abstract}

Keywords: heritage, rural tourism, agritourism, economic development

Cite this articleas: Toderaş, A. (2020). Using G.I.S. Products for Analysing the Potential of Practising Sustainable Tourism and Developing Zece Hotare Village. Territorial Identity and Development, 5(1), 68-98. DOI: http://doi.org/10.23740/TID120204

\section{INTRODUCTION}

In the last fifteen years, the practice of rural tourism and agritourism has reached an increased share in Romanian villages whose tourist resources are capitalized, which has led to the emergence of a series of legislative regulations on the practice of these forms of tourism. Nevertheless, the practice of each form of tourism should be done in a sustainable manner, this recommendation being highlighted by the new development policies in tourism.

The World Tourism Organization (2004, unnumbered) states that "Sustainable tourism development requires the informed participation of all relevant stakeholders, as well as strong 
political leadership to ensure broad participation and consensus building. Achieving sustainable tourism is an ongoing process and requires constant monitoring of impact, introducing necessary preventive and / or corrective measures whenever necessary. Sustainable tourism should also maintain a high level of tourist satisfaction and provide tourists with a meaningful experience, raising their awareness of sustainability issues and promoting sustainable tourism practices among them."

Stănciulescu et al. (2020) consider that "rural tourism is a form of tourism focused on destinations in rural areas, with a functional structure of accommodation and other heterogeneous services" (p. 180).

One form of rural tourism is agritourism. Glăvan (2002) defines agritourism as "a specific form of rural tourism practised by small landowners in the country, usually as a secondary activity, the basic activity being that carried out in their own household, which is the main occupation and source of income" (p.16).

The main objective of this study is to analyse the local resources for the development of sustainable tourism, rural, mountain, ecotourism and agritourism, and to find solutions to attract the tourist flows that will lead to the economic development of the village.

\section{Motivation for choosing the topic and research area}

I chose the village of Zece Hotare as a research topic because I consider it relevant to this study, since the proper setting and capitalization of resources available to the village (e.g. karst relief, landscapes, buildings, knowledge of locals about practising certain customs and trades, etc.) introduce opportunities that create a high potential for various forms of sustainable tourism such as rural tourism, mountain tourism, agritourism, ecotourism, etc. The current trend of the urban population is to get out on the mountains on weekends. Some of them seek to find there only an oasis of peace and recreation, while others want to practise activities as diverse as possible. Zece Hotare village has resources that suit the current trends of tourists.

Another reason why I chose this area is the fact that I have followed the evolution of this settlement for the past ten years. In this regard, we can talk about a decline rather than an evolution of the village. Therefore, in order to stop this decline and restore the balance, we must launch proposals and plans that have a relevant application and observable results of rehabilitation of the situation in the village, the most affected field being the socio-economic.

I also chose this study topic because, except for the document presenting the Sustainable Rural Development Strategy of Şuncuiuş Commune, where this topic is approached at commune level, I could not find this topic among other studied bibliographic resources about Zece Hotare. In order to identify and make proposals for capitalizing on existing resources in the village, the natural, cultural and industrial resources were analysed.

The major difficulty in analysing these resources was the fact that I did not have access to statistical data at the village level, but only at the commune level. This prevented me from making graphs and tables that could have better highlighted the current situation, distribution and classification of resources, and which would have provided accurate data and a higher quality of the study. Under these circumstances, the study has more of a general note. 


\section{THEORETICAL BACKGROUND}

Sustainable development at local level is significant, but global, European, national and regional studies must also be taken into account (cf. Cocean \& llovan, 2008; Havadi-Nagy et al., 2015). Traditionally, the inhabitants of an area are considered to have the main role in the process of sustainable development of tourism (Matiku, Zuwarimwe \& Tshipala, 2020), as well as in the process of environmental conservation in natural protected areas (Zhang et al., 2020, p. 1).

Although tourism is developing in a dynamic way, it is conditioned by factors such as: the preferences of the tourists, the age of the population, the economic resources, the geographical characteristics of an area, etc. Among other things, technological development is an important factor contributing to the development of tourism. However, it is widely recognized that tourism plays a significant role in the local development process (Gavurova, Suhanyi \& Rigelsk, 2020, p. 983). Tourism is a subsystem of the service sector; it has become a profitable and relevant industry in the national economy. The impact that the practice of tourism has on infrastructure can be both direct and indirect (Jurcanu \& Roşca, 2012, p. 86).

Rural tourism is a phenomenon that has taken on a global scale, representing one of the most dynamic elements of the world economic system (Bădulescu, 2004). The global development of rural tourism has been determined primarily by: the multiplication of economic and cultural relations at the global level; the rapid development of the urban environment (many inhabitants of the urban environment are willing to spend their free time in the rural environment): the amelioration of the urban population's financial situation; the improvement of the level of culture, digitalization, modernization of communication routes and means of transport, especially air transport, facilitating intercontinental, continental and national transport (Țurcanu \& Roşca, 2012, p. 86; Tătar, 2009, p. 14).

A key role in the development of rural tourism at European level was the establishment of the European Federation of Rural Tourism (EuroGites), in 1990. It oversaw the operation of the rural tourism network in Europe. Romania has been a member of EuroGîtes since 1993, and in 1994 the National Association of Rural, Ecological and Cultural Tourism in Romania is established-ANTREC (Antonescu \& Antonescu, 2013, p. 123).

According to the statistics of the World Tourism Organization, compared to international tourism, rural tourism has a faster development. Globally, the English are considered the promoters of rural tourism, being the first to discover and enhance the holiday in rural areas, since the eighteenth century. In Romania, rural tourism can be developed as a national specific, because it has an important potential that contributes to the diversification of the tourist offer. As Antonescu \& Antonescu (2013) claim, the three basic elements of rural tourism are: rural space, rural communities and tourist products (p. 121).

In recent decades, rural tourism has grown and become a major economic activity in many rural areas in Romania, such as those in the North-West Development Region. In this region, there are the most picturesque villages in the country, whose beauty is complemented by the cultural heritage of ethnographic areas. The change of the tourist's preferences who opted for spending their holidays or vacation in a Romanian village, to the detriment of other places, contributed to this development (Barbu, Olah \& Barbu, 2010, p. 1). Vasile (2015) states that rural tourism is the key to the development of Romanian tourism (p. 3). Good examples of practising agritourism are the West and North-West Development Regions where agritourism blends harmoniously with agriculture and the Romanian tourist resources. 
The agritourism in Romania is increasingly promoted at European level (Avram, 2015; Ciurea, 2011). Although agritourism in Romania is in its infancy, its development is related to issues that fall in the category of factors influencing and effects of the touristic activity, such as: attracting the population to the rural area in order to increase the number of inhabitants of the Romanian villages, as a result of agritourism; the European funds provided to farmers for rural development (National Rural Development Program for the period 2014-2020); preserving local traditions and customs that are unique in the world (Avram, 2015). In the practice of agritourism, the agricultural activities are combined with the tourist ones. They contribute to the rural tourist offer that should firstly provide: accommodation, spaces for dining and various leisure activities (Ciolac et al., 2019, p. 3).

In the Apuseni Mountains, rural tourism has a high potential due to the natural landscapes, the cultural heritage, the locals, etc. (Moisă, 2006). Also, there is a high potential for practising other forms of tourism, such as: speleological tourism, which is favoured by the presence of karst relief (the largest number of caves and oats in the country is in these mountains); mountain tourism, which is favoured by the almost intact landscapes and the large nu mber of natural tourist attractions, such as waterfalls, meadows, gorges, etc., some of these mountains being included in the Apuseni Nature Park (Guvernul României, Decision No. 230 of March 4, 2003, Annex 1); cycle tourism fostered by the low altitude of the relief and by the gentle slopes (ApuseniMountains-ro.wikipedia.org); agritourism favoured by the presence of locals who are willing to host tourists and cook their food using products from their own household, etc. However, the tourist potential of these mountains is underused (Moisă, 2006). In order to improve this issue, it is necessary to apply the proposals from the National Regional Development Plan for the period 2014-2020, but also those from the National Strategy in the field of Tourism.

The practice of agritourism may be an efficient way for the sustainable development of the mountainous rural environment, the effect being visible on the economic and social level in the concerned community. By practising this form of tourism, the arable land can be capitalized by achieving products that, in turn, generate a source of income. This would also provide possible jobs for young people, preventing the phenomenon of depopulation (Ciolac et al., 2020).

Regarding tourism in the Pădurea Craiului Mountains, the places and tourist attractions in these mountains are presented on various sites that promote tourism, such as: Bihor in pictures (Dragoş et al.), Discover Eco-Romania (Asociaţia de Ecoturism din România, 2020), Travel Guide Romania (lanc, Oroş \& Micula, 2020), etc., but also on the website of the Salvaspeo Bihor County Mountain Rescue Service (Asociaţia Salvatorilor Montani Bihor, 2015). Also, authors such as Drăgan (2007), Bâc (2015), Văetişi (2006), Surd \& Turnock (2000) and others, have conducted scientific studies regarding the phenomenon of tourism in the Apuseni Mountains.

For the evaluation and ranking of tourist resources in the Romanian mountain area, the National Institute for Research and Development in Tourism of Bucharest (INCDT) conducted a study reaching a ranking of mountain ranges based on the attractiveness index score for each mountain. According to this study, the Pădurea Craiului Mountains are part of the third group of four (Zaharia, Zaharia \& Tudorescu, 2005, p. 191).

Regarding tourism development in Bihor County, Benţe \& Benţe (2008) stated that it would be appropriate if the tourist offer were supplemented with various activities related to the season and the tourist profile, such as organizing fairs, cultural events, cave tours, etc. It is important 
to create new attractions, different types of accommodation, new leisure activities and new services (Benţe \& Benţe, 2008, p. 251). These recommendations can be materialized by developing and promoting rural and mountain tourism and agritourism.

The tourism in Șuncuiuș Commune is known at national and international level, due to the capitalization of tourist resources to a significant extent. These are promoted on various media such as: ROtourism the Magic of Travel (RoTourism, 2015-2016), I love Romania (Eu iubesc România), Digi24 (Mihuţ \& Szilagyi, 2017), Tourism Aleșd (http://turismalesd.ro/defileulcrisului-repede-zona-suncuius-vadu-crisului-si-platoul-zece-hotare//, etc. Among the existing tourist attractions in Zece Hotare village, the only promoted one in the information sources is Zece Hotare karst plateau. Șuncuiuș Agrement Center was established in 2013, subordinated to the Ministry of Youth and Sports, which proves the increased interest for practicing tou rism in this village.

Following the research of the existing bibliographic sources, I did not find scientific studies on practising tourism in Zece Hotare. Instead, I found studies on karst and bauxite resources in this villages, made by Brejea et al. $(2008,2011)$. I also accessed bibliographic sources written by the following authors: Bran Florina, Ciangă Nicolae, Csősz Ioan, Ghereş Marinela, Mitrache Ștefan, Nistoreanu Puiu, Pastor loan, Petrea Rodica, Răcăşan Bianca-Sorina and Rusu Teodor, with studies concerning rural tourism (Bran, Marin \& Simon, 1997; Ciangă, 1998; Pastor, 2006; Petrea \& Petrea, 2001; Răcăşan, 2018), agritourism (Csősz, 1996; Csősz, 2007; Ghereş, 2006; Mitrache et al., 1996; Pastor, 2006), ecotourism (Nistoreanu, 2003; Pastor, 2006) and rural development (Rusu, Moraru \& Cacovean, 2011).

The relevance of this study stems from the fact that it deals with a topic about Zece Hotare that has not been researched in detail so far: the possibility of practising rural tourism, agritourism, ecotourism, cycle tourism, etc. in this village. Another element of novelty that this study brings is the creation for the first time of the map that shows the delimitation of the hamlets, this being a useful element for tourists who want to visit the area.

\section{METHODOLOGY}

Several methods were used in conducting this study. The first method used was the documentation method. This method was applied by consulting the existing bibliographic and cartographic sources. I studied some of them in the library of the Faculty of Geography, BabeșBolyai University of Cluj-Napoca. I also consulted the topographic plan of the village within the Șuncuiuș City Hall. Following the research of the bibliographic resources (from the accessed sources), the results were processed and correlated with those achieved from the field research organised over the 10 years (2010-2020) in Zece Hotare village, as well as in the neighbouring villages.

The deductive method was applied in this study by observing the phenomenon of tourism development of the entire commune, then customizing this phenomenon only at the level of Zece Hotare village.

The observation method was used both directly and indirectly. The direct observation me thod was used through visits to the studied area, in order to gather new information and to observe the current situation of the village of Zece Hotare. I have done this stage several times, starting with 2010, the last trip being made on July 18, 2020. The method of indirect observation consisted in consulting the topographic plans of the village and in analysing satellite images to 
observe the evolution of the built fund, land use and areas that have been deforested. The se observations were made with the help of an observation plan regarding several aspects.

The dialectical method was used to highlight the connections between the structural elements of the village, but also to identify the potential impact of tourism on neighbouring areas, which may be primarily the increase in the number of tourists. This could be achieved by organizing guided tours that include tourist attractions in nearby settlements, such as in Roșia commune: Water Mill, Roșia Trout Farm, Crystal Cave in Farcu Mine, Cuţilor Gorges, Lazuri Gorges; in Tomatic village: the lake formed after the excavation in a bauxite lens, the plateaus with sinkholes, the Old Man's Cave; in Vadu Crișului settlement: the pottery centre with its white pottery, where white clay is processed, this being unique in south-eastern Europe, the waterfall and Vadu Crișului cave, Poarta Zmeului cave; in Șuncuiuș locality: Peştera Vântului, Peștera Moanei, Izbândiș cave and spring; in Bălnaca village: Ungurul Mare cave, Lavinia beach which is unique in Romania being located in Crişul Repede Gorge, which continues on the territory of Șuncuiuș and Vadu Crișului settlements. Another impact would be the sale of products made by locals in neighbouring localities, for example white ceramic pots made in Vadu Crişului, honey, dairy products, etc. Also, the development of tourism in Zece Hotare village could be an impulse for the development of the tourist infrastructure in the neighbouring settlements.

The method of the case study was used by choosing and studying the possibility of deve loping the village by practicing rural tourism, choosing from the entire commune only Zece Hotare village as study topic. The method of analysis was applied by separate analysis of each component that can be considered a resource in tourism development. By the method of synthesis, these elements were recomposed into a whole, in order to achieve the overvie w of the analysis made and its effectiveness.

The survey method was used through the oral interview I took from the locals. I asked the locals (mostly people over 30 years old), whom I met during my visits to Zece Hotare, questions about: the number of tourists visiting the village; the tourist attractions in the area (what information I should know about them); their openness to hosting guests (to which the inhabitants replied that they would welcome them, which indicated the possibility of practising agritourism); the customs and traditions they knew and if they would like to share them with tourists; which were the traditional dishes; which they considered to be the most beautiful place in their village; what products were made in their own household, or whether they would be willing to sell; I also asked them how far they thought the boundaries of the ham lets extended, etc.

One of the interviews I had was with the owners of a boarding house who offered me information about the tourists' country of residence who stayed there and visited the village. Their answer also showed the interest of foreign tourists to visit the village. The answers of the locals convinced me that they would like to practise agritourism, rural tourism, as well as other forms of tourism in their village, willing to share with others the beauties and customs of the places.

The GIS method (Geographic Information Systems) and the cartographic method were used to create the cartographic resource made using ArcGIS 10.6 software. Also, one of the most important methods used is the regional method, which can be said to be one of the most complex, because, in order to be applied, it uses the information retrieved from other methods. I used this method for the identification and spatial analysis of the structural elements of the village; highlighting the resources that contribute to the development 
potential, as well as the dysfunctions and the factors responsible for the current imbalances in the village; proposing solutions and suggestions for their implementation in order to exploit the potential and reduce the existing imbalance; beneficial highlighting of the tourism development in this village.

\section{RESULTS AND DISCUSSION}

\section{Geographical location}

Within the national territory, Zece Hotare village is located in the North-West part of Romania, on the administrative territory of Bihor County, in the east and southwest of Suncuius commune (Figure 1). The entire territory of the village is included in Natura 2000 site ROSCI0062 Crișului Repede Gorge Pădurea Craiului, being a site of community relevance, under the administration of the Centre for Protected Areas and Sustainable Development Bihor - Pădurea Craiului Branch (Figure 2).

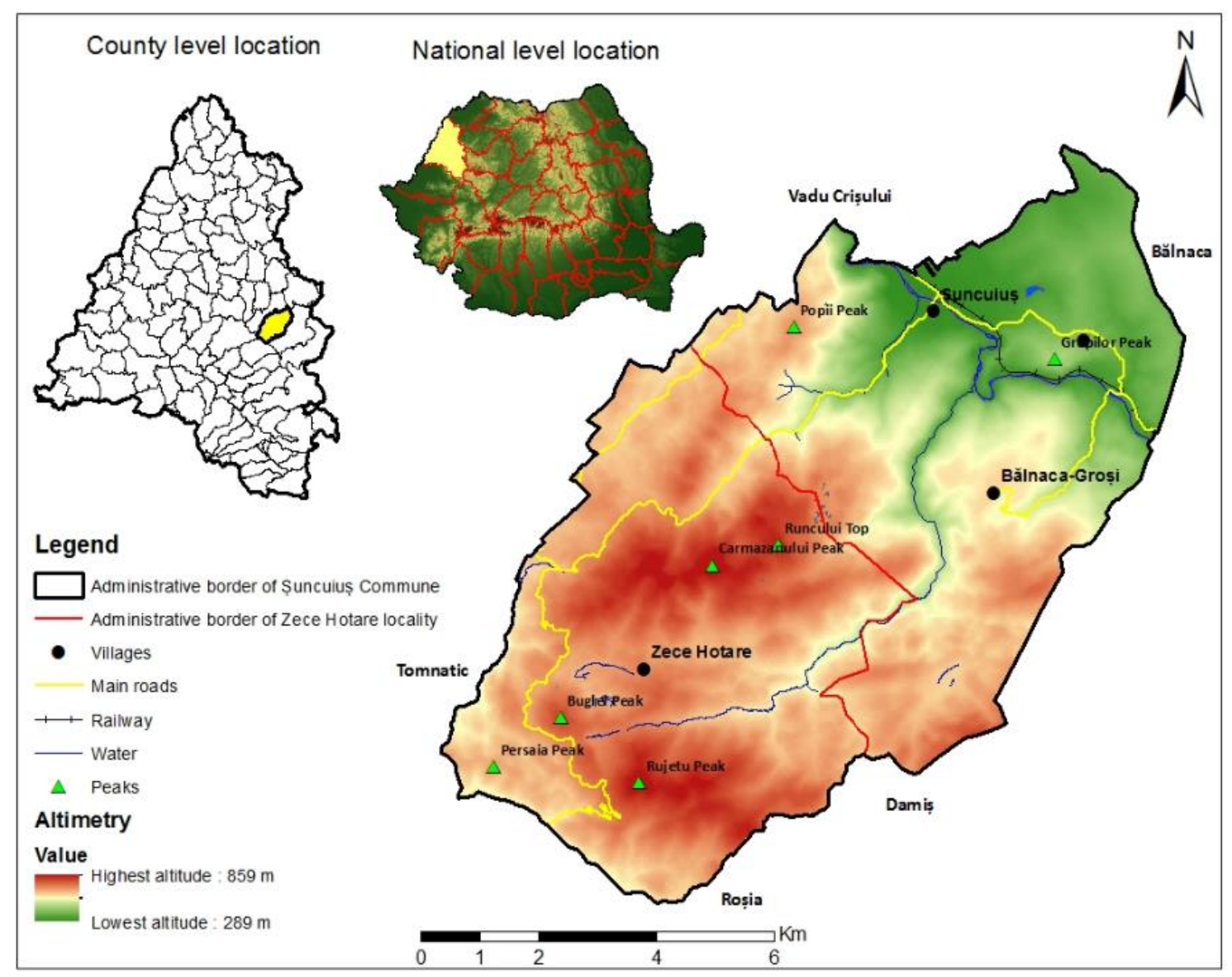

Figure 1: Framing in the territory of Zece Hotare village and Șuncuiuș commune Source: the author, based on vector and raster data from Geofabrik GmbH \& OpenStreetMap Contributors, 2018 and USGS Earth Explorer 
From the point of view of the location within the geographical units, the territory of the village overlaps the northern part of Pădurea Craiului Massif from the Apuseni Mountains, being in an area with karst relief. As relief forms, the mountain peaks with altitudes exceeding $800 \mathrm{~m}$ predominate, being covered with forests, hayfields, and pastures.

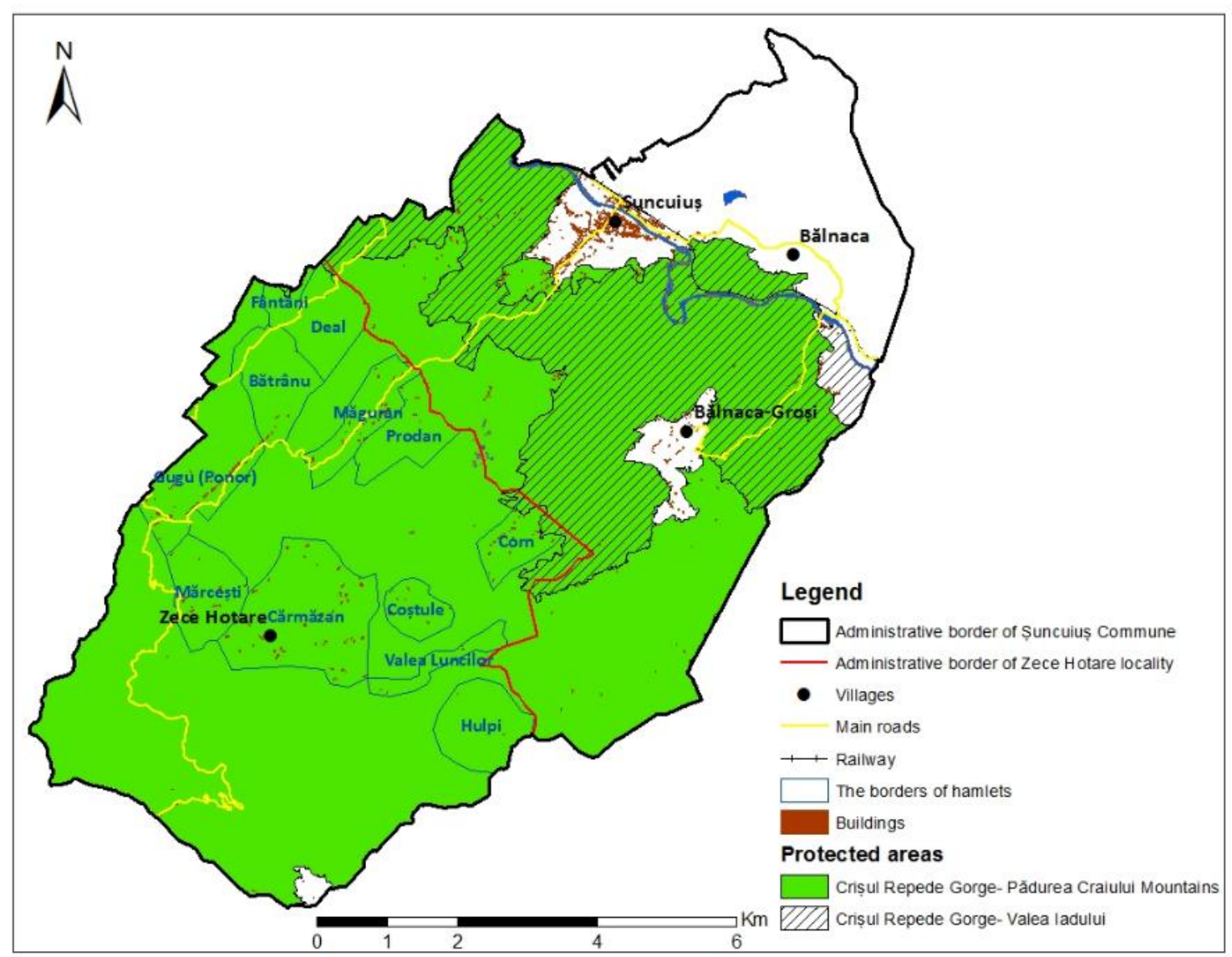

Figure 2: Hamlets and protected areas in Șuncuiuș Commune

Source: the author, based on vector data from Geofabrik GmbH \& OpenStreetMap Contributors, 2018; Ministerul Mediului, Apelor şi Pădurilor, 2015 and data obtained by the author, in the field (the borders of hamlets)

The administrative boundary of the village depends on how far it borders the neighbouring settlements, namely: Șuncuiuș village (Șuncuiuș Commune) in the east, Damiș village (Bratca Commune) in the southeast, Roșia village (Roșia Commune) in the south, Tomnatic village (Vadu Crișului Commune) in the west, and Vadu Crișului village (Vadu Crișului Commune) in the north, all these villages having also a great potential for tourism development. This potential is stressed by the presence of karst relief and the formations created by this type of relief. For example, in Șuncuiuș there are many caves, among which the Wind Cave is the longest cave in Romania.

\section{Resources and potential}

In recent years, the practice of rural tourism has become an option for the economic development adopted by more and more villages that know how to capitalize on their 
resources. Analysing the resources that this village has, I considered that practising tourism would be a good option for its economic development. In order for this activity to become profitable, it is necessary to create new tourist attractions so that the tourist offer to be as diversified and interesting as possible.

According to the data presented by the World Bank, Zece Hotare has an average index of local human development and an average potential of economic development (Figure 3).

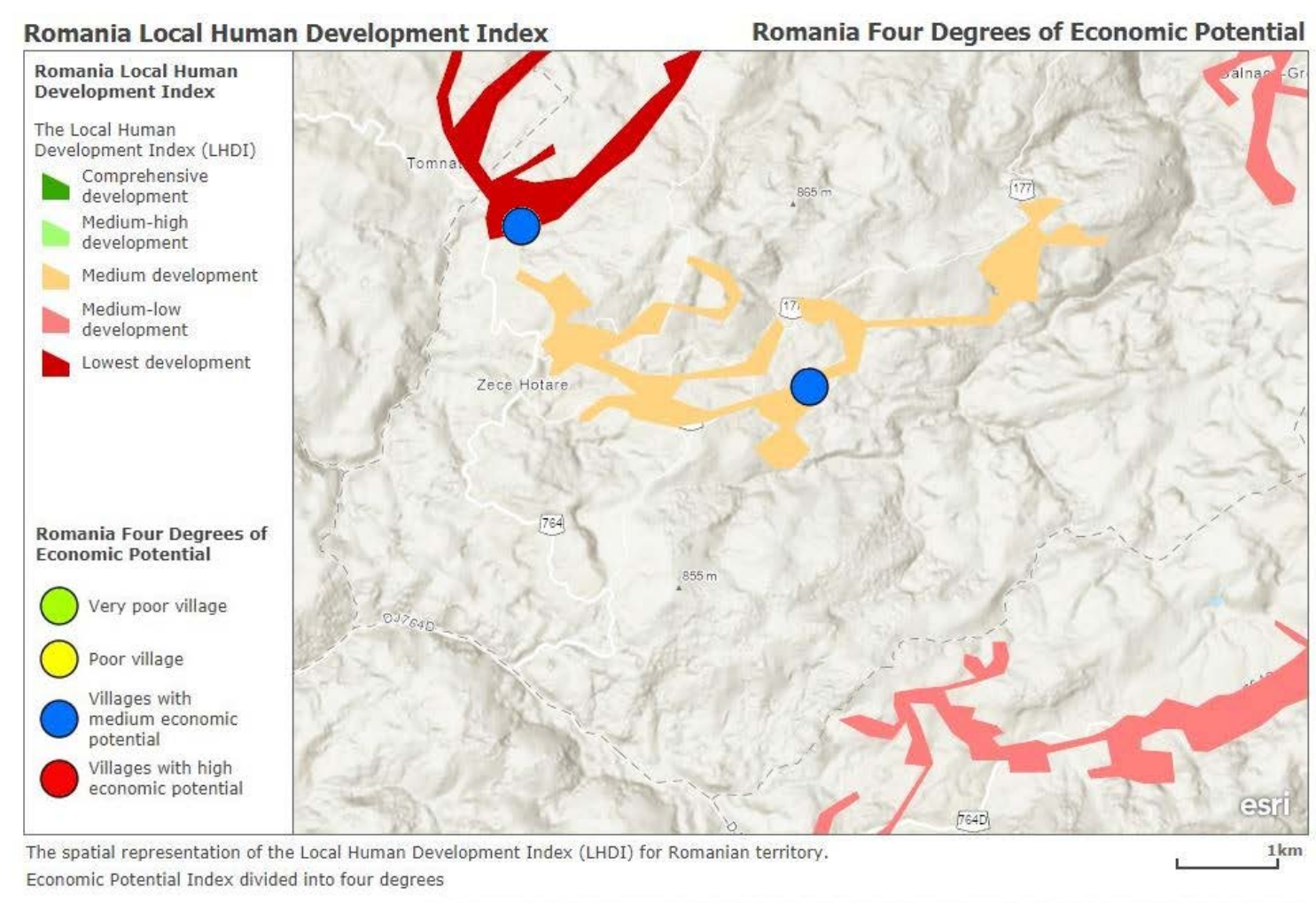

Esri, Intermap, NASA, NGA, USGS I Esri Romania, Esri, HERE, Garmin, INCREMENT P, METI/NASA, USGS

Figure 3: Romanian local development index and Romania's four degrees of economic potential Source: data from 2016,

https://www.arcgis.com/home/webmap/viewer.html?useExisting=1\&layers=11f5a50eef2e4b67829f1997454d2b61 and from 2017,

https://www.arcgis.com/home/webmap/viewer.html?useExisting=1\&layers=c0cfacee49ca4db89c175e8684ba6ecf

\section{Natural resources and ways to capitalize on them}

Being located in the mountainous area (part of the less-favoured areas category; cf. also Havadi-Nagy et al., 2015), the lands of the village are covered with deciduous forests comprising a variety of species of trees and shrubs, which are listed as follows: willow, lime, chestnut, poplar, oak, beech, birch, hazelnut, maple, ash, etc. This diversity of trees also offers a complex ecosystem for the animals, of which the most common are: the wolf, the fox, the deer, the wild boar, the squirrel, the thrush, the blackbird, the cuckoo, the woodpecker, the goldfinch. They make up the flora and fauna of the existing forest area on the territory of the village. The tourist can observe the whole ecosystem and especially the fauna could be an element of tourist attraction. 
The forest areas are combined with the meadows, hayfields, and agricultural land, as can be seen in the land use map (Figure 4). Some of the hay is mowed and then used as animal feed in winter. Tourists who want to experience this can also take part in the process of mowing, turning, gathering, and building hay bales.

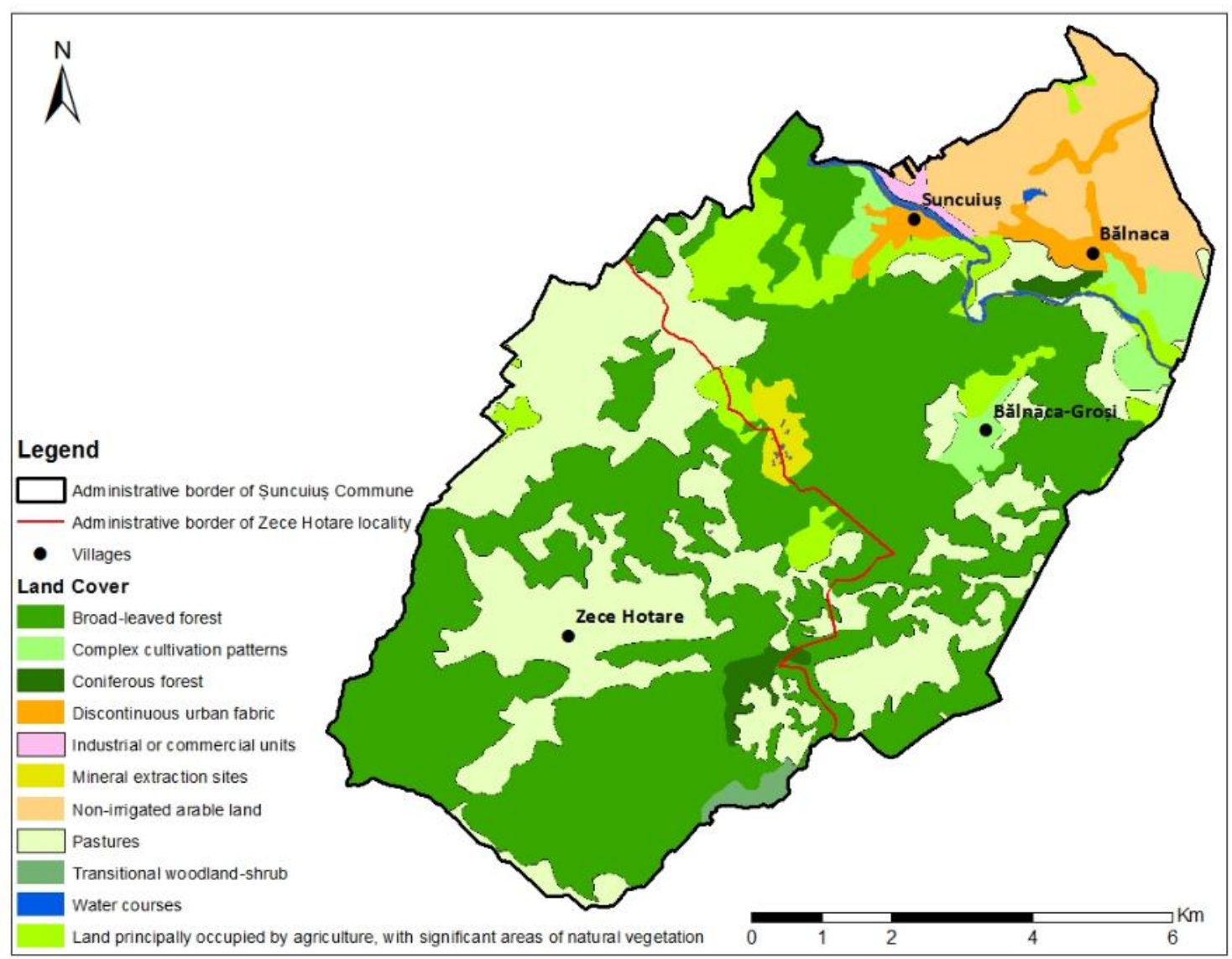

Figure 4: Land use in Șuncuiuș commune

Source: the author, based on vector data from Geofabrik GmbH \& OpenStreetMap Contributors, 2018; Copernicus Programme, 2018

Forest landscapes are natural resources that, if properly managed, contribute to the development of sustainable tourism (Sgroi, 2020). In the richness of meadow grasses and hayfields (Figure 5), there are a lot of medicinal plants used by locals in treating various diseases and making medicinal teas, so the interested tourist can be trained in identifying and preparing these plants as natural medical remedies, promoting thus herbal medicine. In order to facilitate the identification of plants by tourists, thematic paths can be created along which to place signs with pictures of plants and their appellation.

The mountain fruits of shrubs usually found on the outskirts of the forest, such as hazelnuts, but also in the meadow area - raspberries, strawberries, blackberries, cranberries, blueberries, rosehips - are fully exploited in local gastronomy, some being used in jams, juices, cakes, syrups, etc. Forest sponges are also used in gastronomy, being prepared in different ways according to local recipes. 
The gastronomy (Figure $6 \mathrm{C}$ ) of this village is rich and varied depending on the season. While the food is being prepared, the tourists can be invited to attend or even be involved in its preparation, if they wish, so that they learn new recipes.
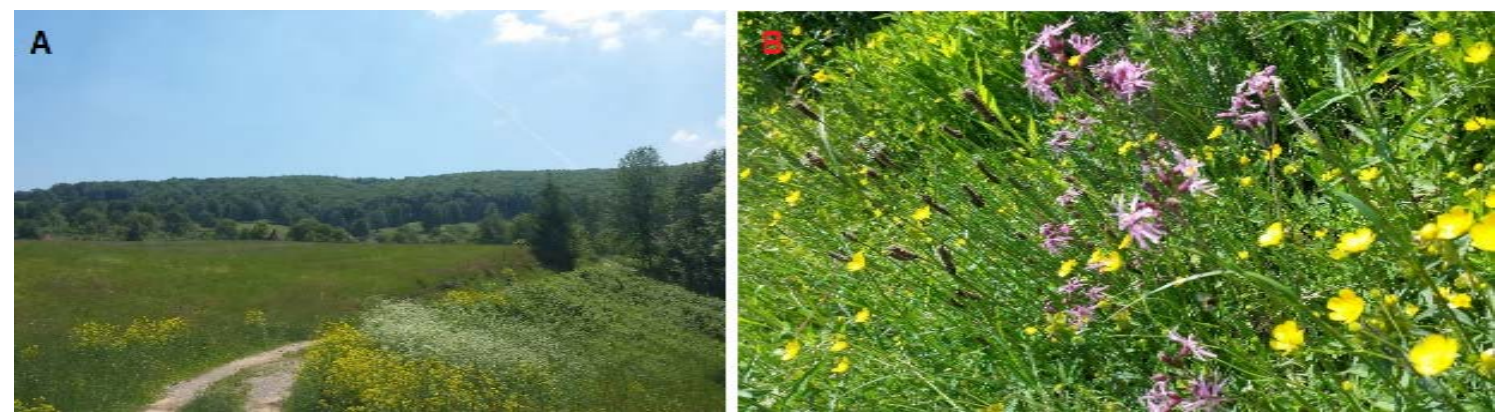

Figure 5: A- Meadows; B- Diversity of plant species

Source: Alina Toderaș, 2016

The main source of food from the households of the locals is represented by the crops of various vegetables and cereals. The fruits are taken from their own orchards, which are usually found in the garden behind the house. Due to these crops, the owners have fresh and natural products. Animal husbandry (Figure 6A, 6B) is another asset of the village, both for obtaining food such as milk, meat, and for the picturesque landscape offered by sheep herds, horse studs, etc. The tourist can be trained how to ride, riding being a very popular sport.
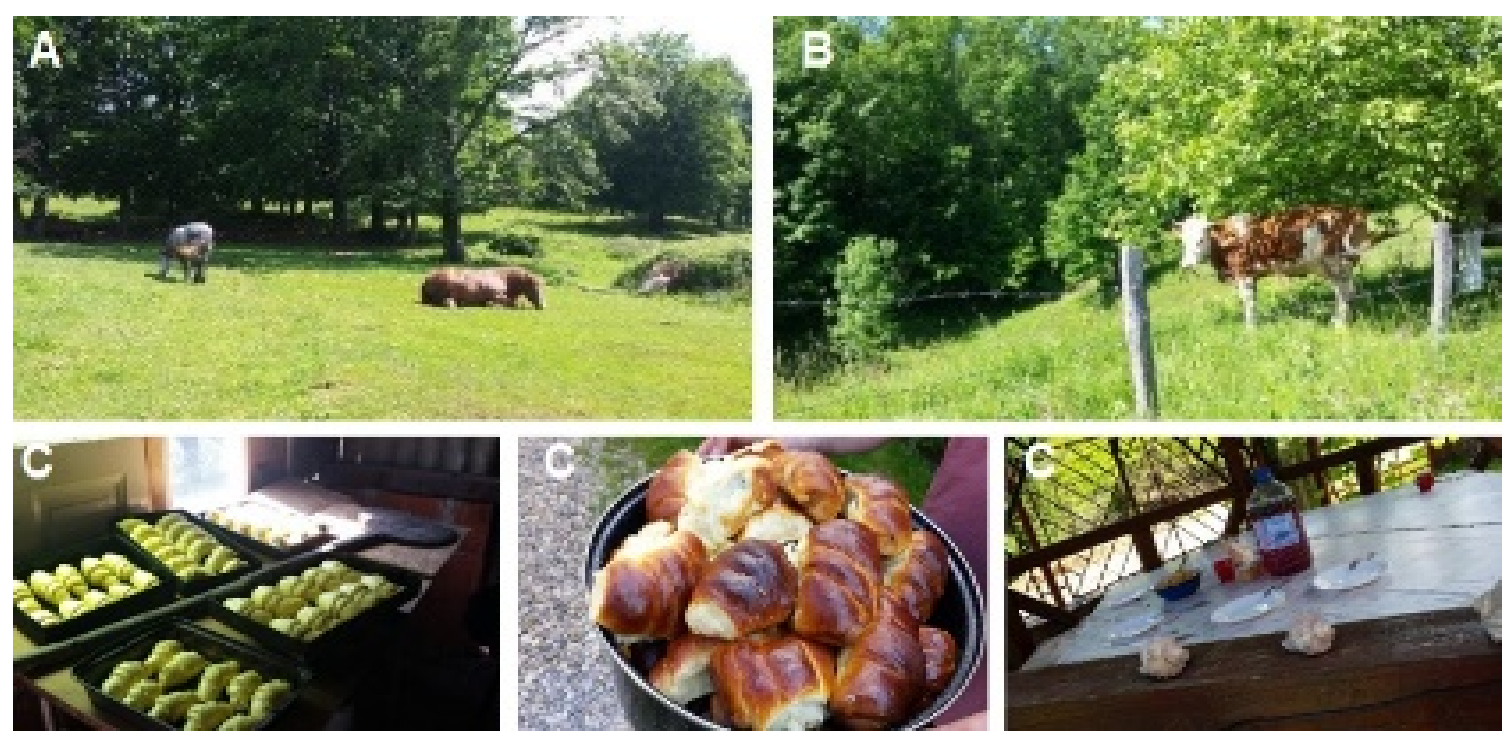

Figure 6: A-Horses; B- Cattle; C-Local gastronomy

Source: Alina Toderaș, 2016

A large inflow of tourists would also lead to the expansion of arable land and more intensive livestock farming, so it would be possible to result in a surplus of cereals, vegetables, and fruit that could be sold in agri-food markets in neighbouring towns or even in cities, if they were kept in the conditions necessary for their non-alteration; the milk could be collected in dispensers and sold to dairy companies that collect the milk; animals can also be sold at 
slaughterhouses. All these activities would be a source for increasing the locals' income. However, this would also involve the risk of destroying the natural landscape, very difficult to be rebuilt. Some solution to capitalize on local gastronomy products, most of which are organic products, could be the organization of culinary festivals, fairs, and the creation of local boutiques to sell beekeeping products, tea plants, organic personal care products made of local resources, etc.

Air and water quality are high, being oxygenated and unpolluted, due to the large areas covered with forests, located at altitudes between approximately 600 and 800 meters. This would be another source of attraction for tourists who want to spend their time away from various types of pollution. This also applies to the natural landscapes that have remained almost intact in some places.
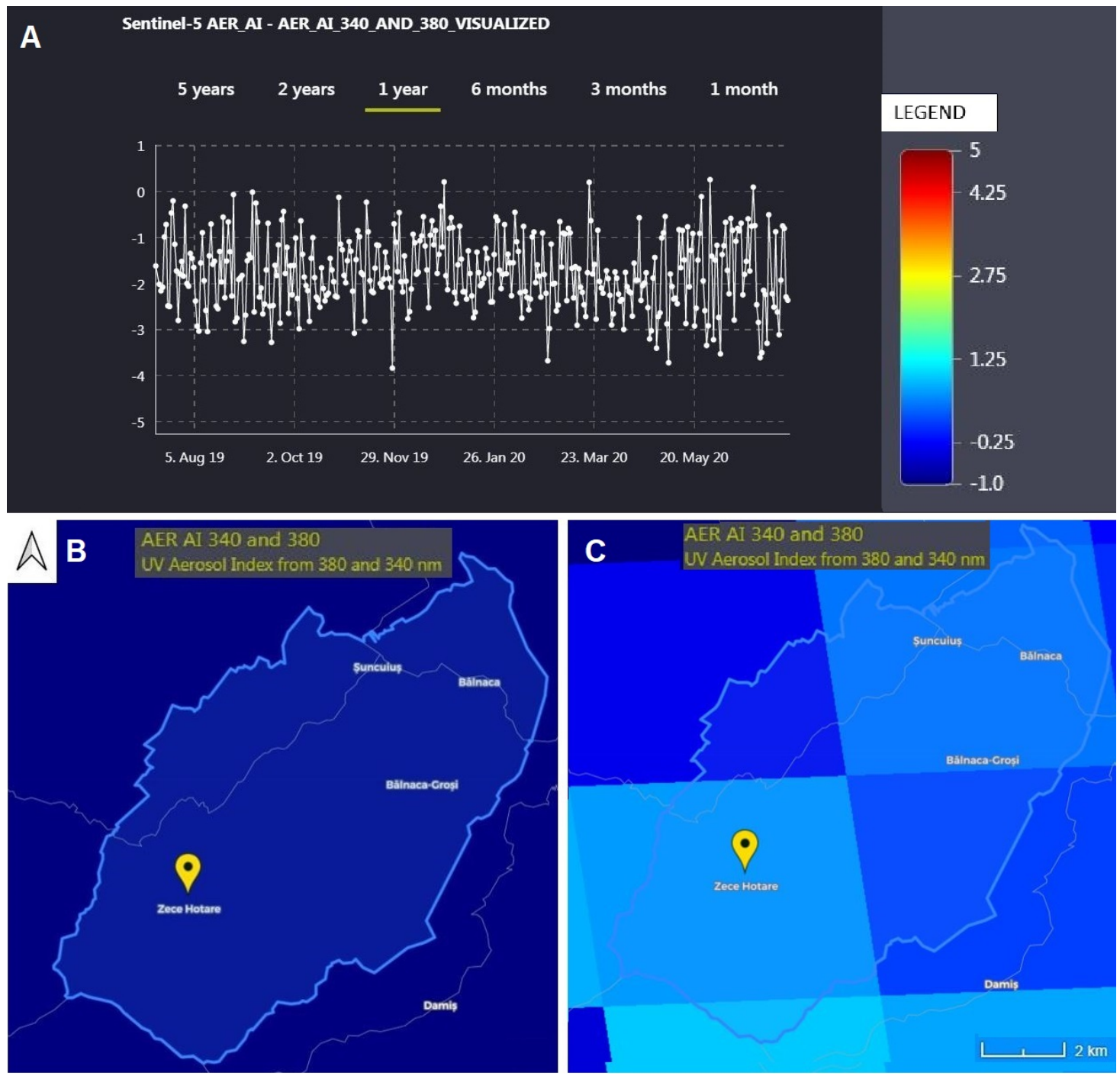

Figure 7: A- Graph representing the variation of UV Aerosol Index; B- Map with the lowest score of UV Aerosol Index (November 28, 2019 -the day on which the lowest score was registered); C- Map with the highest score of the UV Aerosol Index (May 30, 2020 - the day when the highest score was recorded) 
In order to highlight the air quality, the following parameters were analysed, on satellite images taken by the TROPOspheric Monitoring Instrument (TROPOMI) sensor on board the Sentinel - 5P satellite: UV aerosol index (AER_AI), Carbon Monoxide (CO), Nitrogen Dioxide $\left(\mathrm{NO}_{2}\right)$ and Ground-level Ozone $\left(\mathrm{O}_{3}\right)$. The last year was chosen as the measurement period from July 15, 2019 to July 15, 2020. The scores of the parameters are represented as graphs and maps. The data was taken from the ESA EO BROWSER application.

The graph A (Figure 7) shows the UV aerosol index scores that vary between -3.9 and 0.26 , these being the lowest and highest score (also represented on maps), falling into the category of low scores. These show that people can be exposed to the sun because they will be safe and will not suffer sunburn on the skin (Figure 7).
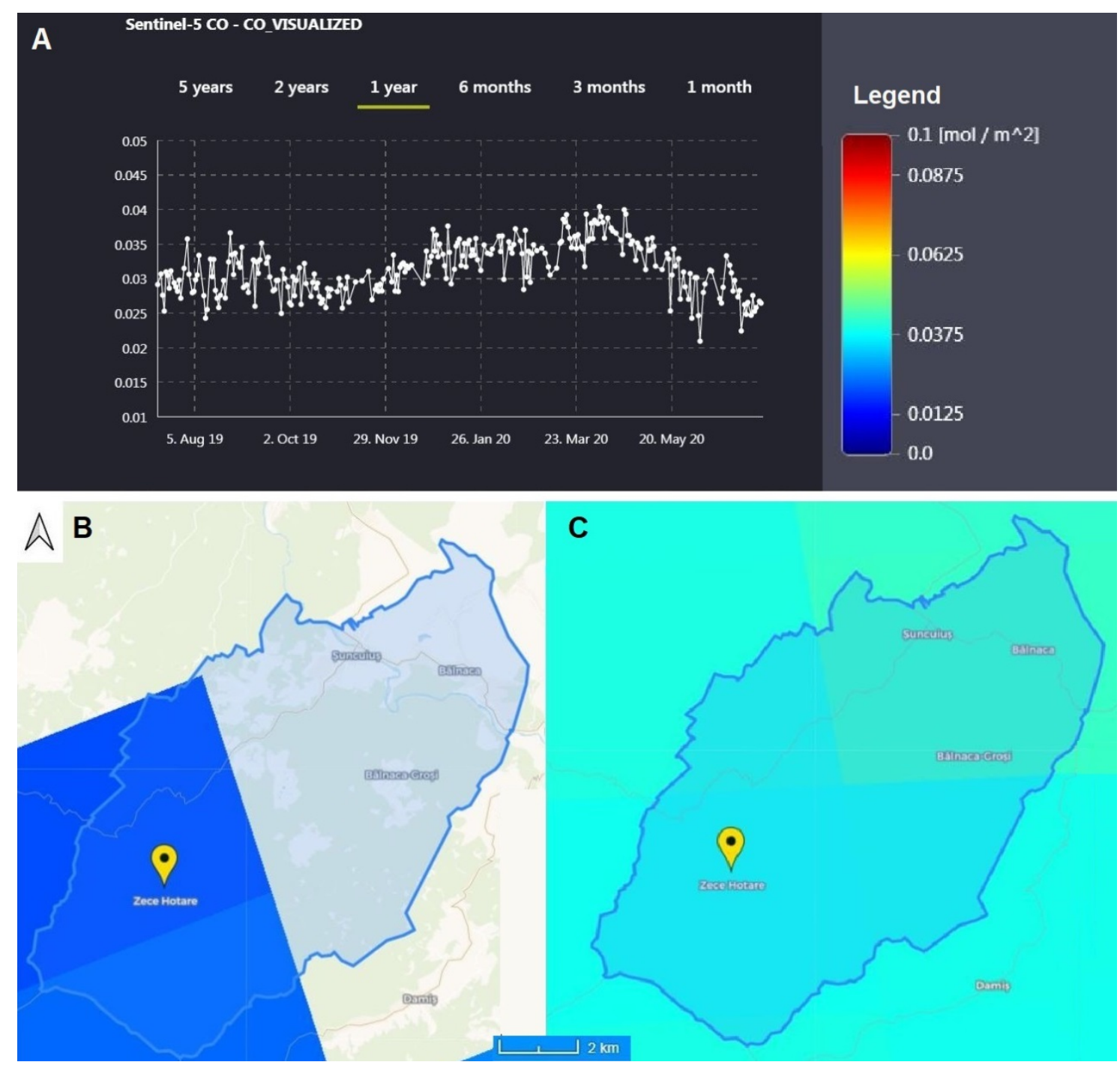

Figure 8: A- Graph representing the variation of Carbon Monoxide (CO); B- Map with the lowest scores of Carbon Monoxide (CO) (June 7, 2020 - the day when the lowest score was recorded); C- Map with the highest scores of Carbon Monoxide (CO) (April 7, 2020 - the day when the highest score was recorded) 
The graph above shows the Carbon Monoxide (CO) scores that vary between 0.021 and 0.041 $\left(\mathrm{mol} / \mathrm{m}^{2}\right)$, these being the lowest and highest values (also represented on maps), falling into the category of low scores. The presence of low $\mathrm{CO}$ values is also due to the large areas covered with vegetation that use this gas in the process of photosynthesis, absorbing it and turning it into oxygen (Figure 8).
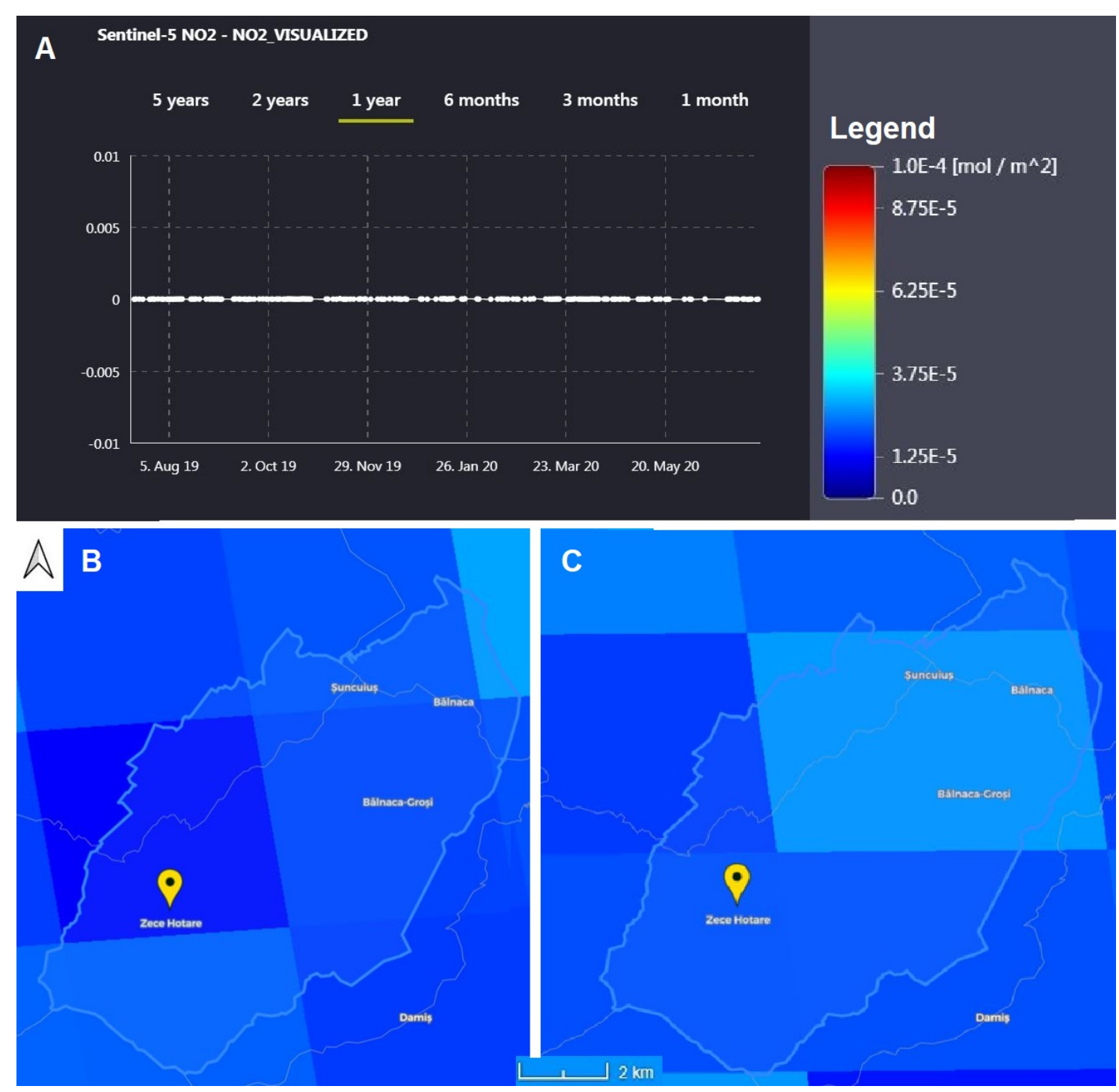

Figure 9: A- Graph representing the variation of Nitrogen Dioxide $\left(\mathrm{NO}_{2}\right)$; B- Map with the lowest scores of Nitrogen Dioxides $\left(\mathrm{NO}_{2}\right)($ April 7, 2020 - the day when the lowest score was recorded); C- Map with the lowest scores of Nitrogen Dioxide ( $\mathrm{NO}_{2}$ ) (July 6, 2020 -the day when the highest score was recorded)

Source: ESA EO BROWSER, Nitrogen Dioxide $\left(\mathrm{NO}_{2}\right)$

The graph above shows the values of Nitrogen Dioxide $\left(\mathrm{NO}_{2}\right)$ that remains constant around 0 $\left(\mathrm{mol} / \mathrm{m}^{2}\right)$, as can be seen in the representation on the maps (Figure 9). 

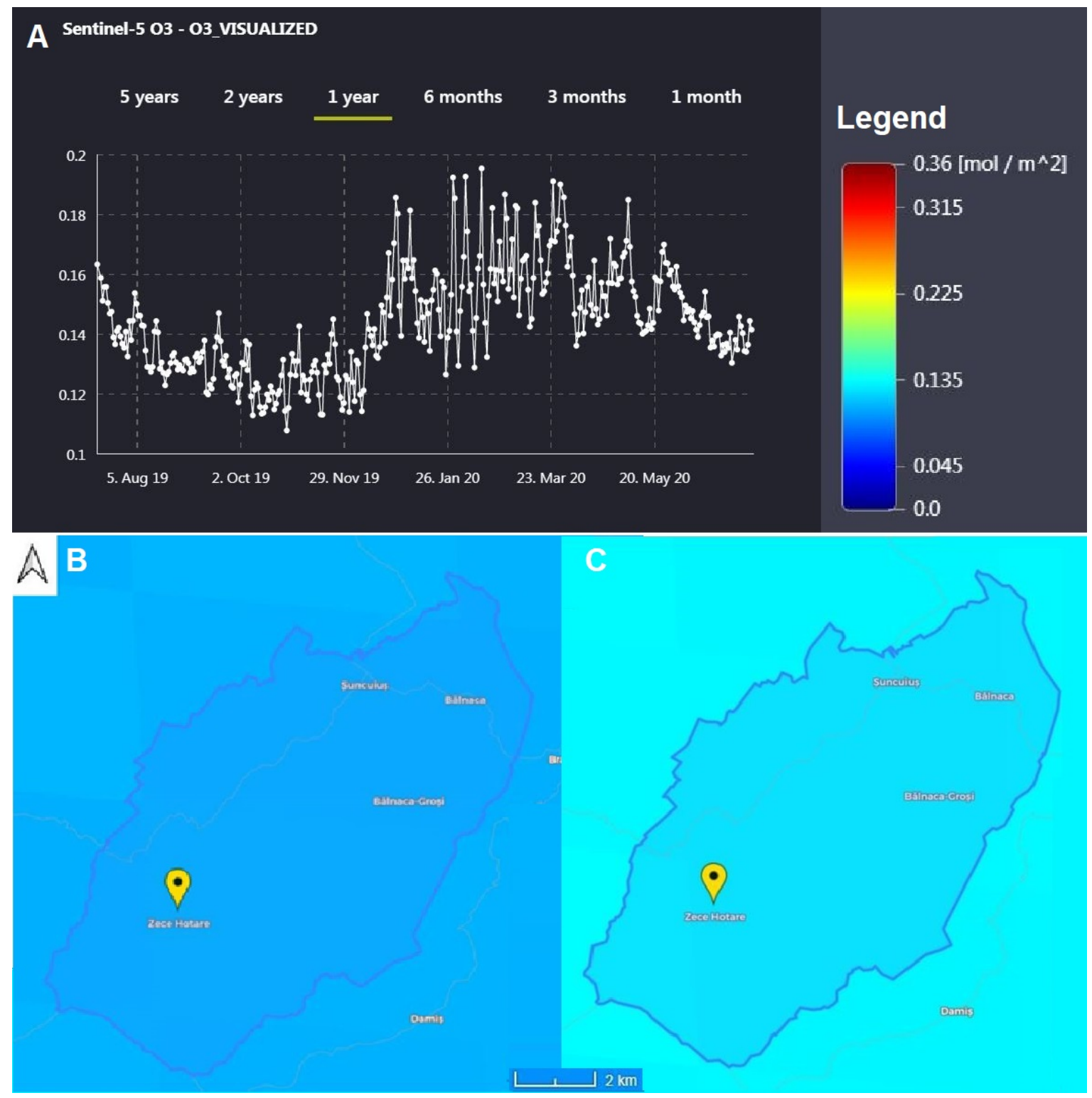

Figure 10: A- Graph representing the Ground-level Ozone $\left(\mathrm{O}_{3}\right)$ variation; $\mathrm{B}-\mathrm{Map}$ with the lowest score of Ground-level Ozone $\left(\mathrm{O}_{3}\right)$ (October 28, 2019 -the day when the lowest score was recorded); C- Map with the highest score of Ground-level Ozone $\left(\mathrm{O}_{3}\right)$ (February 17, 2020 the day when the highest score was recorded)

Source: ESA EO BROWSER, Ground-level Ozone $\left(\mathrm{O}_{3}\right)$

The graph above shows the Ground-level Ozone $\left(\mathrm{O}_{3}\right)$ scores which vary between 0.4 and $0.1985\left(\mathrm{~mol} / \mathrm{m}^{2}\right)$, these being the lowest and highest scores (also represented on maps). They were much lower in 2019, compared to 2020, when their decrease has been recorded since June (Figure 10). The low score of these parameters is due to the small number of inhabitants, therefore the human activities which cause pollution are few, which also indicates the protection of the environment by the inhabitants through the activities they perform.

The karst relief is perhaps the most important factor of tourist attraction in the area, here Zece Hotare plateau being the largest karst plateau of the Piatra Craiului Mountains. It is sprinkled 
with a lot of sinkholes, ovals, blind valleys (Figure 11C) (Morar, 2013). The Old Man's Cave can also be found on this plateau (Figure 11A). The presence of the karst relief and the forest fund offers the possibility to organise outdoor hikes, to experience the tourist routes especially set for practising horseback riding or cycling tourism.
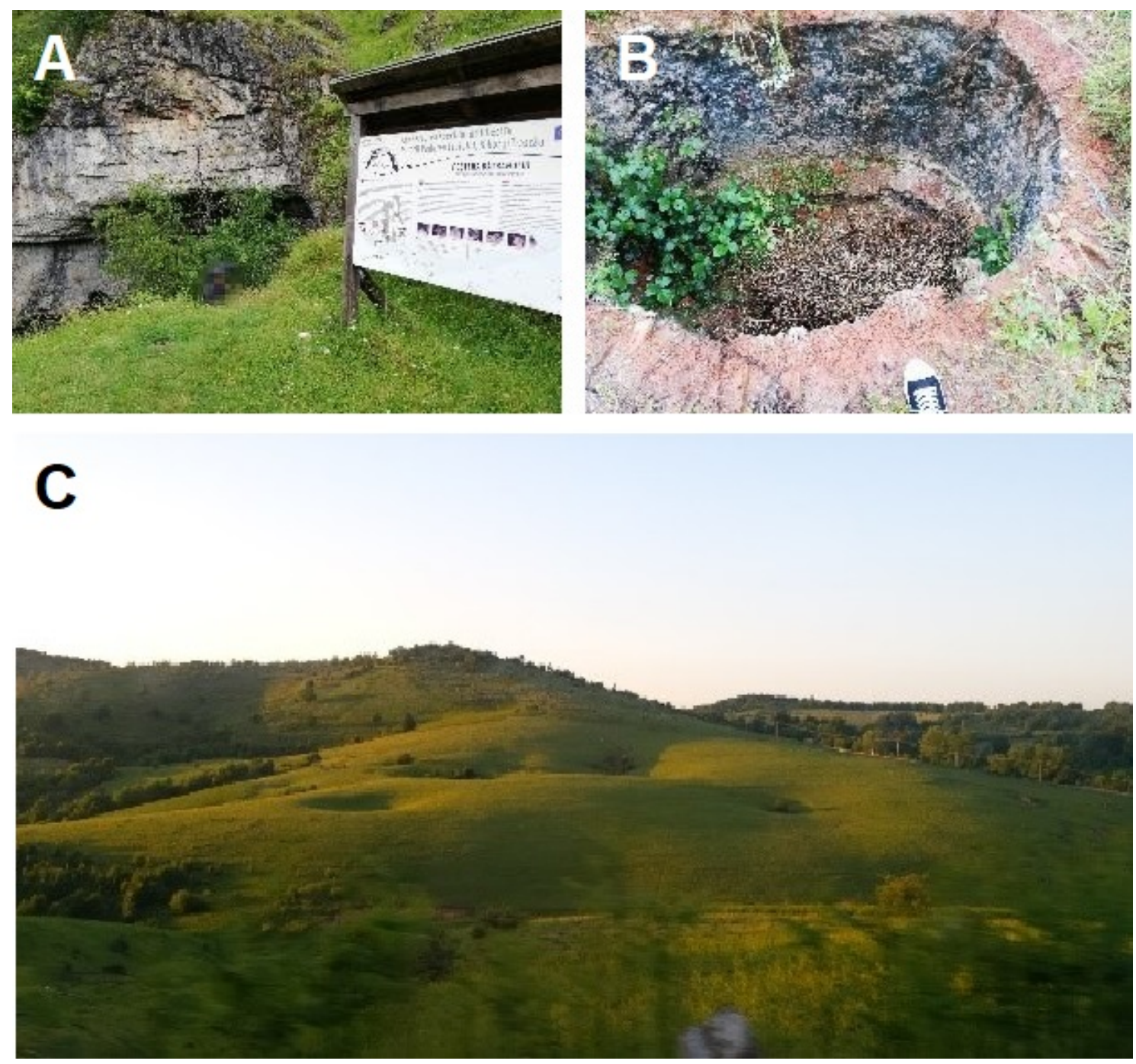

Figure 11: A-The Old Man's Cave; B- The inside of the oven of an open fireplace; C- Karst relief sinkholes

Source: Alina Toderaș, 2020

Due to the exceeding existence of limestone and wood, the inhabitants of this area have practised the process of burning limestone since ancient times. The first step in the process of making limestone is the extraction of limestone which is done according to traditional methods. This is extracted with various tools, such as: chisels, crowbars, hammers, pickaxes, etc. The second step is to fill the oven (Figure 11B) with stones that are placed as a vault, the foundation and the walls on which the vault rests are made of large stones, and the top of the vault is built of small stones. The third step is to burn the stone with wood, and the fire must be kept without interruption for a week or even two weeks, depending on how large the 
capacity of the oven is. The combustion temperature can reach 1.000 degrees Celsius. The burning process takes place between April and August. The last step is to open the oven and remove the limestone, which is done only after the oven has cooled down, about a day after the burning stopped. After completing the process of making limestone, this is sold in neighbouring regions, being transported tens of kilometres by cart pulled by horses. The sale of limestone contributes to the inhabitants' income.

\section{Cultural resources}

In the past, the locals had a strong faith in customs and tradition, which, for them, were above the Orthodox Christian faith, but nowadays many of these customs have been forgotten in the mists of time and are no longer practised. We encounter the same situation in the case of crafts. The objects with which the crafts were practised can also be found in the households of the locals as handicrafts (Figure 12). They gave up practising the crafts, which in the past we re indispensable to their lives, because now these do not provide any income. However, it could be proposed to practise some of them for tourist purposes, such as: pottery-capitalization of the clay resource, sewing, wood carving (making certain tools and wooden vessels), etc. The se traditional activities could be carried out especially by the elderly, who, in turn, could teach even the youngest. Thus, the elderly would play an active role in local social life (Cocean, 2014). Today, the traditions are performed only on certain holidays, especially at Christmas and Easter.
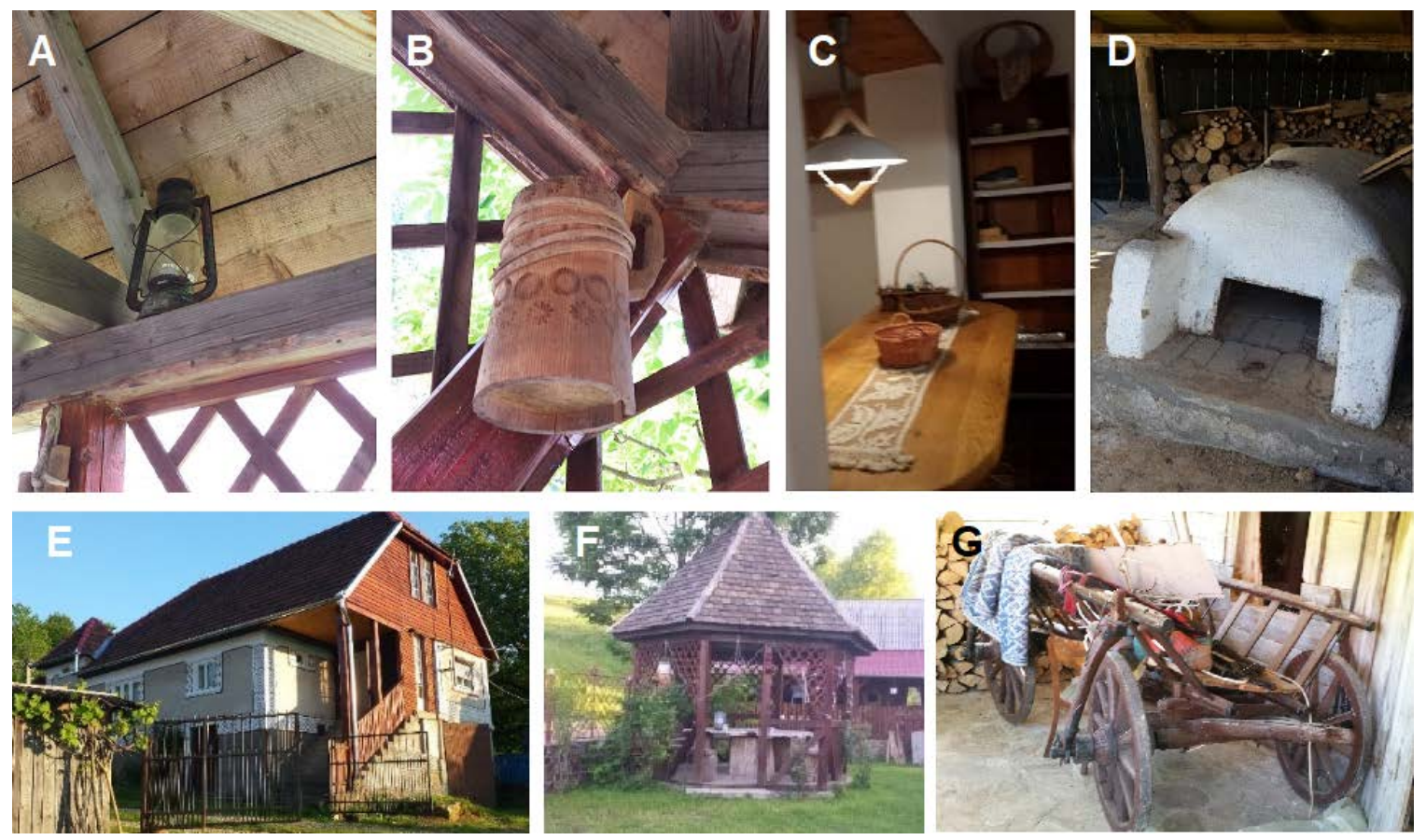

Figure 12: A- Lamp; B- Wooden cup; C- Interior of a peasant household; D-Traditional oven; E- A traditional house; F- Place for serving meals in the household yard; G-Wooden cart 
From the point of view of the built fund (i.e. heritage, cf. Ilovan, 2009), many of the houses have a specific traditional architecture, being built of wood and stone, this showing the capitalization of the village's resources since the past.

\section{Industrial resources}

Due to the bauxite resources that the village has, two mines for the exploitation of bauxite resources were built on its territory: Cărmăzan mine and Ana mine. However, because of socio-economic changes, they were closed in 1996 (interview with Toderaș Dumitru). If these mines were restored, they could be capitalized as industrial tourist resources, so tourists could be introduced to the way in which the extraction of bauxite resources from the underground was practised.

Also, the existence of clay resources led to the creation of clay mining quarries, which could be included on the list of tourist attractions. The clay extraction works could be observed by tourists from a gazebo designed for this purpose.

A tourist landmark with scientific value could be the old weather station (currently nonfunctional, but it stores the equipment). Tourists could be shown how to analyse and re trieve weather data from a weather station.

Taking all the above into consideration, the high tourist potential of the area can be noticed. However, it is necessary to establish a development plan for the locality to capitalize on, so that tourists can benefit from all these leisure opportunities and leisure choices offered by a mountain rural household.

\section{The history of the village}

Zece Hotare village has been documented since 1913, but according to the villagers, it is 200 years old (Popa, 2014). It is a mountain village with a scattered structure that, in the past, consisted of ten scattered hamlets - whence its name. These were: Deal, Bătrânu, Măgu ran located in the north of the village, Gugu, Tomnatic - in the west of the village, Valea Mierăie in the southwest of the village, Brejeşti-in the south of the village, Corn - in the northe ast of the village, Hulpi - in the east of the village, and Cărmăzan - in the centre of the village. After the change of administrative boundaries, the last three hamlets are no longer part of Zece Hotare. But due to its large surface, the inhabited area has expanded and three other hamlets have appeared in the village area - Coştule, Valea Luncilor and Mărcești -, as well as two groups of households that emerged as an extension of the already existing hamlets and received different deprivations. The two groups of households are Fântâni (which occurre d as an extension of Deal hamlet due to its large extent. It was given the name Fântâni because the locals grave water to their animals here), and Prodan (which occurred exactly as Fântâni, only near the hamlet of Măguran). If these two were united with the hamlets in whose extension they are, the village would comprise ten hamlets again: Bătrânu, Cărmăzan, Corn, Coștule, Deal-Fântâni, Gugu (Ponor), Hulpi, Măguran-Prodan, Mărceștiand Valea meadows.

Figure 2 hosts the first map made with the delimitation of Zece Hotare hamlets, because so far no such delimitation has been made on cartographic support, but was made only verbally by locals regarding the area with which they identify. The inhabitants of the hamlets used the name of the hamlets when asked where they lived and knew how far those stretched. In order to draw the boundaries of the hamlets, I consulted with the surveyor of the Șuncuiuș 
commune hall, who is an old local of the village, as well as with other locals who are over 50 years old and have been part of the history of this village from birth to the present.

\section{Socio-economic aspects}

Until 1997, when the closure of the bauxite mines began, the village had a strong mining specificity. Due to the mining that was practised in the village before 1997, the locals had jobs, but with the closure of the mines the population decreased. Consequently, because the incomes from agriculture did not cover the minimum of living standards, the population migrated to other villages in search of jobs (for details on the problems of disadvantaged areas in Romania, see llovan 2005, 2006).

Today it is a predominantly agricultural and forestry village, the only industrial activities that take place here being the exploitation of clay resources and of the forest fund. However, given that the current industrial activities are carried out with modern equipment and technological means, which require only a small number of employees, they do not provide a sufficient job offerfor the locals. Animal husbandry is also practised, such as horses, sheep and cattle, which serve the locals as a source of food and income. Some of the exploited wood is used by the locals in the architecture of their houses, in the creation of furniture and sometimes in the creation of the household annexes (Figure 13). Although generalized, this profile offers us a great perspective on the village.
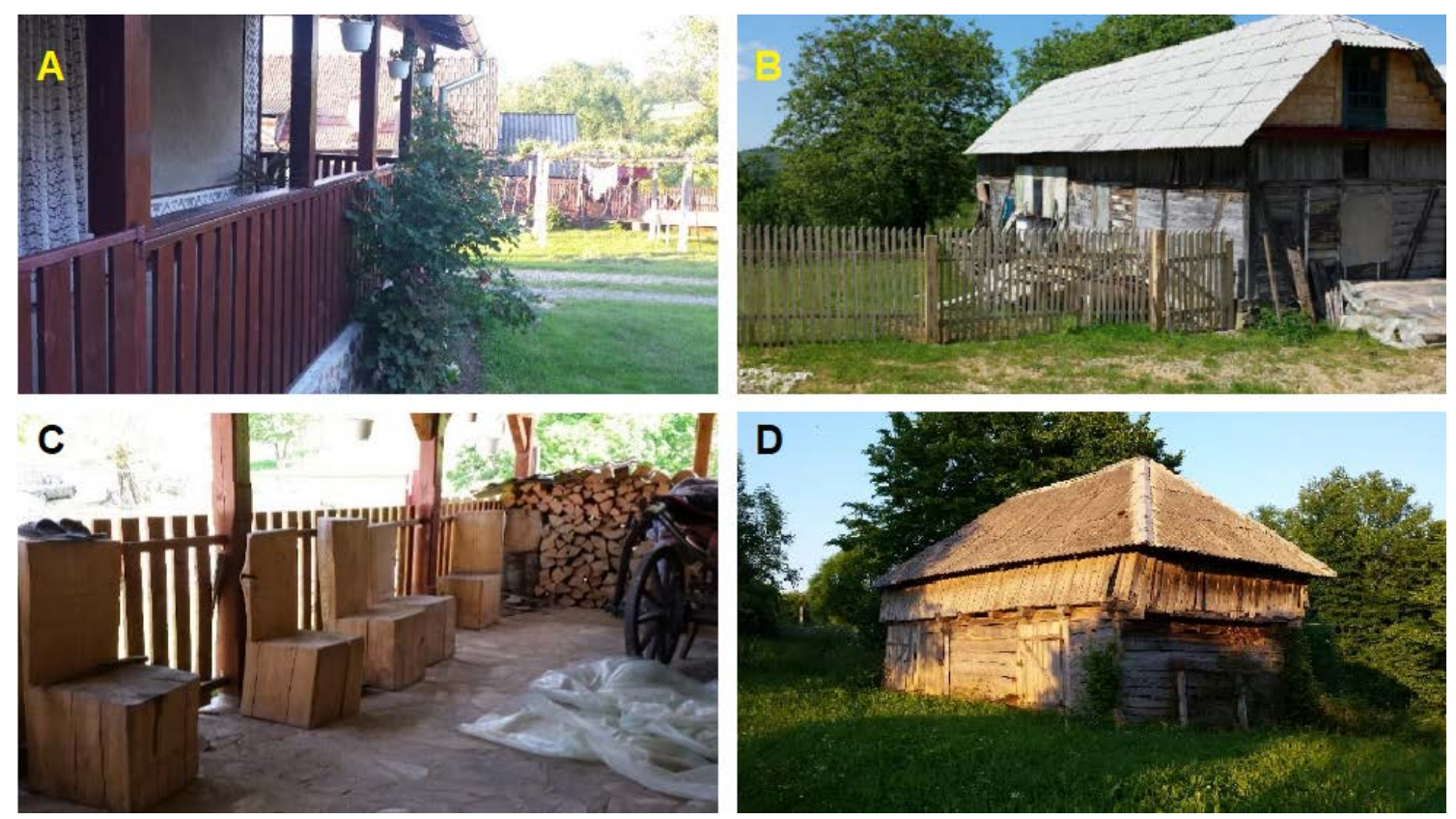

Figure 13: A-The use of wood in the architecture of homes; B- Wooden fence;

C- Wooden chairs; D- Wooden stable

Source: Alina Toderaș, 2016

\section{Accessibility}

The road infrastructure of the locality is made of a county road, DJ 764 (under modernization), which connects the cities of Aleșd and Beiuș, three communal roads: DC 177 Ș uncuiuș - Zece Hotare, DC 36 Corn - Cărmăzan, DC 38 Topile - Pojorâta, and several neighbouring and forest 
roads. They are interconnected with other roads outside the village, such as DJ 108-I Tilegd Bratca, DC 165 Bălnaca - Chirmăș, DC 273 Bălnaca - Bălnaca - Groși, thus facilitating the access of tourists to the area.

Among the potential emerging poles of tourists, there are also cities such as: Oradea, ClujNapoca, Timişoara, Bucharest, Budapest, etc. Tourists coming from different locations can also reach Şuncuiuș by train, because the settlement is crossed by Bucharest-Oradea railway, Oradea being an international station, which favours the railway connections for foreign tourists who choose to use the train as a means of transport. In Șuncuiuș station, high-speed trains of three railway companies also stop, as well as a variety of trains that intensify the railway traffic, thus smoothing the flow of passengers according to the schedules. Travel tickets can be purchased at the train station, but they can also be purchased online. The train station also has a rest area and other facilities.

For the transportation of tourists from Șuncuiușstation to Zece Hotare village, transport trips can be organized at hourly intervals that will fold with the time when the trains arrive at the station. Tourists who come in organized groups from abroad can land at Oradea or Cluj-Napoca airports and from there they can travel by train, bus, or rent a car to get to Zece Hotare.

\section{Basic and tourist infrastructure}

\section{Basic infrastructure}

Referring to the built fund, there are both old houses, built for decades (even since 1900), but also recently built homes (since 2005) (Figure 14).
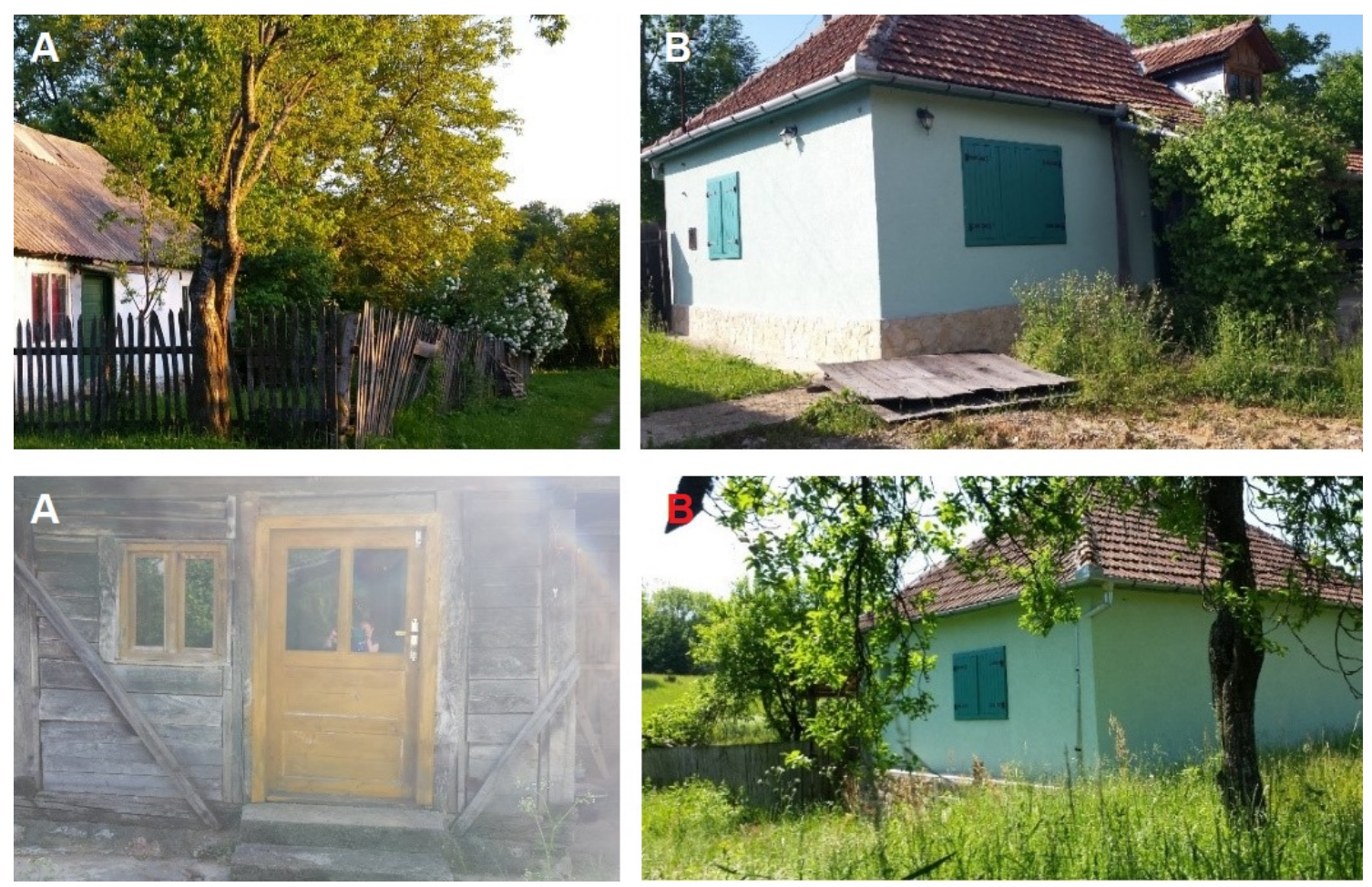

Figure 14: A- Old houses; B - New houses in the hamlet of Gugu (Ponor) 
Electricity supply and public lighting are provided throughout the village. Regarding the supply of drinking water, the main source of supply are the springs that flow into water basins, and from there, through underground pipes, the water flows from the water basin, and reaches the tap in the household of the locals (Figure 15). Because the distances between groups of houses are long, they feed more from more sources, but there are also cases whe re only one household is fed from one source. The significant number of water resources is due to both the karst relief and the layer of clay which is impermeable, thus favouring the maintenance of the groundwater at shallow depths and the accumulation of water resources. The sewerage of the water network is currently underway.
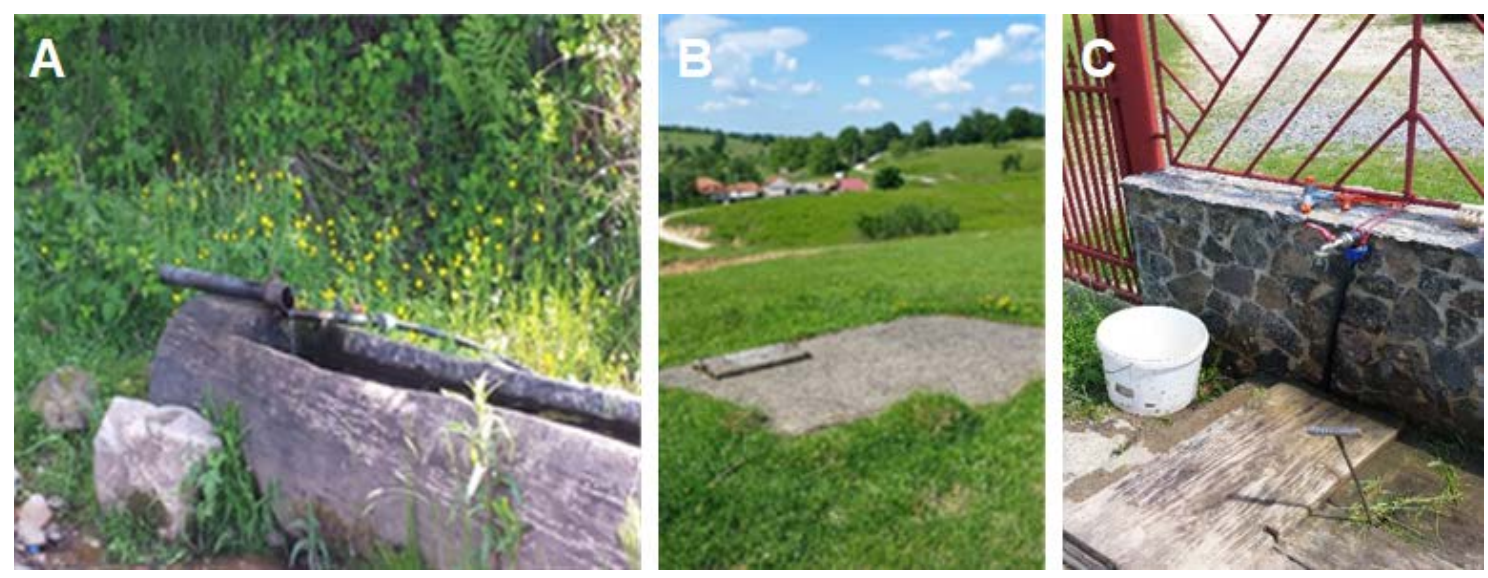

Figure 15: Falling water supply system.

A-spring; B- watertank; C- household water installation

Source: Alina Toderaș, 2016

\section{Tourist infrastructure}

The accommodation infrastructure consists of two tourist pensions: Casa Anuța (owned by a French citizen) and Casa Bătrână (owned by Dutch people) (Figure 16). There is also a tourist refuge, Zece Hotare Tourist Refuge and The Observatory built by "Don Orione" Charity Society with the help of European funds, whose official opening took place on July 15, 2020. In this study, we proposed two more accommodation options to diversify the accommodation. Another alternative concerning accommodation can be represented by the creation of camping places, where tourists can camp with a tent or caravan. Tourists could also stay in the residence of the welcoming peasants. In order for the peasants' houses to become accommodation spaces, it is necessary to give the owners an instruction regarding this aspect.

Currently, the public catering infrastructure is limited only to the dining place in Casa Anuța boarding house. Casa Bătrână Guesthouse has a kitchen where tourists can prepare the ir own meals, but, at the moment, it does not offer tourists the possibility to serve meals. The kitchens in the peasants' houses could be part of the public catering infrastructure, the tou rist being offered authentic local dishes. There could also be places in the gardens of the households where one can dine.

The recreational infrastructure is completely lacking, although the village has a great potential for the creation of a diversified leisure infrastructure. Regarding this aspect, we mentioned some proposals in this study. 

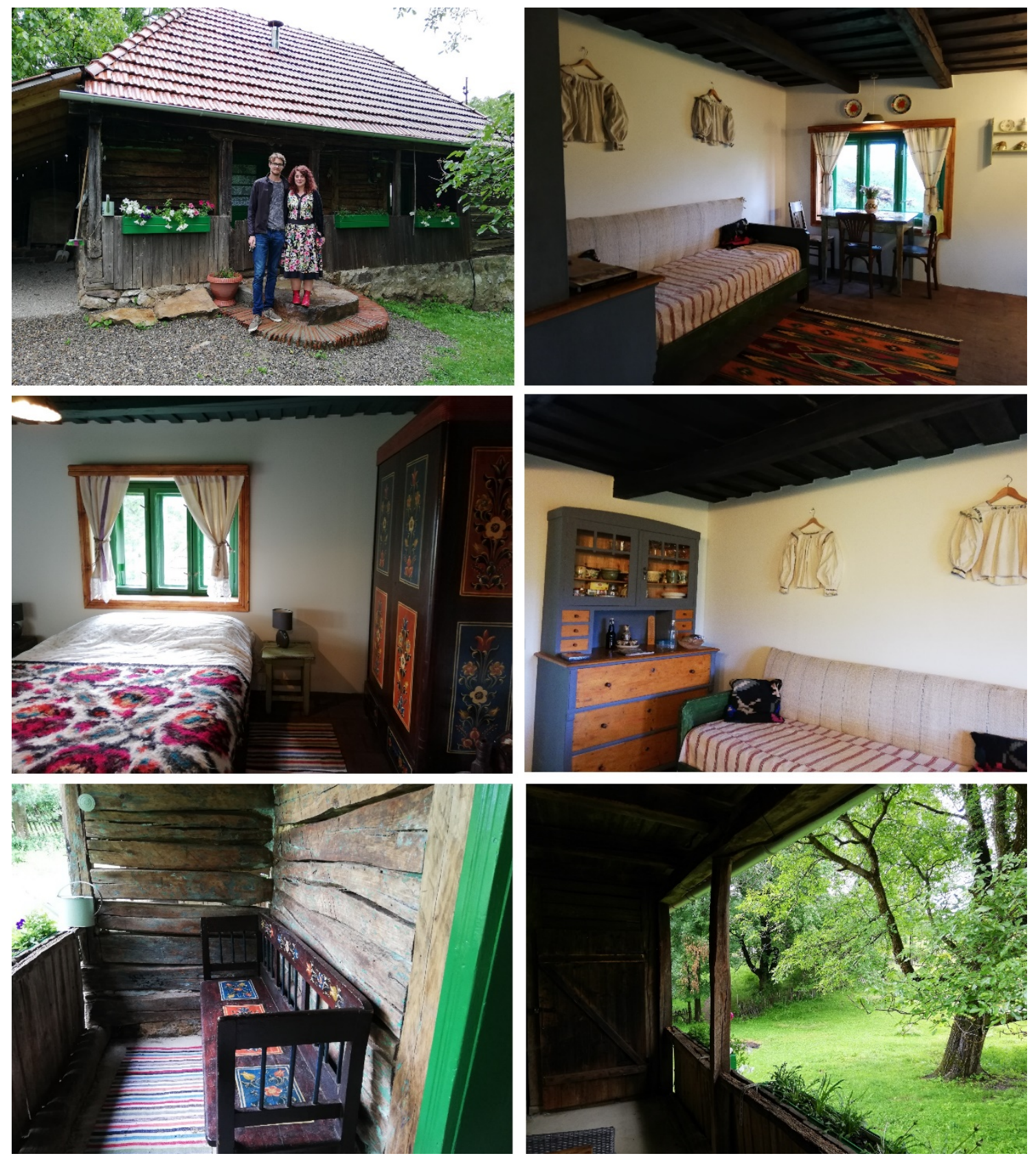

Figure 16: Casa Bătrână Guesthouse, inside and outside

Source: Alina Toderaș, 2020

The SWOT analysis

\section{Strengths}

- One of the strengths is the beauty and conservation of the natural environment highlighted by the presence of karst relief forms, the village being included in Natura 2000 site ROSCl 0062 Crișului Repede - Pădurea Craiului Gorge.

- The clear waters, the fresh air, and the low level of pollution, almost non-existent, represent an advantage of the village for attracting tourists.

- Tourists can be lodged in the two existing tourist pensions, and can buy agri-food products made by the locals in their own households. 
- The access to the settlements is enabled by the communal roads that connect with the county roads, this being done through several places, from Șuncuiuș, Tomnatic, Roșia.

- The built fund represents another asset for practising rural tourism, as well as the knowledge of the locals about customs, traditions, and various trades that they still practise today.

- In this village, several forms of tourism can be practised, such as: agritourism, ecotourism, cycle tourism, mountain tourism, thematichiking, organizing camps, etc.

- The weather conditions are favourable for tourism every season, the tourist offer being adjusted depending on the season.

\section{Weaknesses}

- The tourist potential of the village is insufficiently promoted;

- The locals do not speak any foreign language;

- The population is elderly and few in number, because the youngest have migrated to the urban environment, out of the need to find a job;

- The road infrastructure is undergoing modernisation, being under reconstruction;

- The existence of a small number of tourist pensions and the non-existence of arranging other types of places for accommodation;

- Lack of tourist infrastructure;

- In some parts of the village, there is no access to the communication network;

- Lack of parking areas.

\section{Opportunities}

- Creation of a tourist infrastructure;

- Building a larger number of boarding houses and creating other types of accommodation such as places for camping, peasant homes, glamping, etc.

- Diversification of the touristic offer by creating opportunities for tourists, which are nonexistent in the neighbouring settlements (e.g. themed trails for collecting medicinal plants, horseback riding, creating routes for cycling, learning trades, fairs with local products, organizing events, etc.);

- Creating new jobs that would slow down the migration of young people;

- Creating a web page to promote tourism in the village;

- Offering the possibility to carry out training courses for practising traditional trades;

- Increasing the incomes that would contribute to the economic development of the village;

- Attracting funds for the modernization of the entire infrastructure of the village;

- Capitalizing on local culinary products by creating brands;

- Creation of viewpoints;

- Arranging ski slopes for skiing in winter, when the snow cover enables this;

- Introducing the village to different tourist circuits;

- Capitalization of agricultural lands.

\section{Threats}

- A threat to attract tourists in this village could be represented by the competition given by the neighbouring settlements of Șuncuiuș and Vadu Crișului, but also this threat could be turned into an opportunity, if the tourist offer would arouse the interest of tourists visiting neighbouring settlements, to discover the village of Zece Hotare as well. 
- Any action also involves a risk. In this case, if the proposals are made, there is a risk of anthropogenic change of the environment in the areas where these constructions or arrangements will be located.

- There is also a threat of increased traffic and environmental pollution because of the large number of tourists, if they do not behave responsibly towards the environment.

- In case of non-intervention of local planning services from the local council of Şuncuiuș commune, in order to carry out projects that will restore the balance of the village system, there is a risk that the migration phenomenon will be stressed due to the continuous decline of the socio-economic context as a result of its restructuring (Cocean, 2014). All these lead to a lack of opportunities to reach the income that the population needs to support itself.

\section{Results and proposals}

Some of the points that should be reached in this plan are listed below. Firstly, in order to be able to practise agritourism in this village, the locals should be open to this idea. However, from the results of the interviews, this aspect would not be an impediment; on the contrary, the locals would be happy to have the opportunity of hosting tourists, as most of them are very hospitable. In fact, the hospitability is a specific feature of the mountain peasant. This would involve accommodation and serving the tourist's meal in the host's house. Tourists would consume only traditional products made in the kitchen of the household. For this, the household must comply with the standards necessary to carry out these activities, stated in the Tourism Law. To this end, locals should be provided with accommodation instructions for tourists.

A negative factor that could intervene is the fact that many of the locals do not know any foreign language. Currently the village has two tourist pensions, Casa Anuța and Casa Bătrânească, but it would be indicated to build other pensions, located at greater distances from each other, in order to provide the accommodation of tourists on the entire surface of the village, according to on the area and activities which they prefer.

The non-modernized road infrastructure was until now a major problem of the village in terms of tourism, being an obstacle in visiting these areas. The access to some areas is possible only by off-road vehicles, but starting with this year (2020), the county road DJ 764 is being modernized, which is a significant access route to the village. If the existing communication routes were modernized, the village could make the town a polarizing one in terms of tourist flows, because the transport infrastructure connects cities such as Aleșd, Beiuș, Oradea, ClujNapoca with the existing villages nearby.

Regarding the practice of recreational activities, the following should be proposed:

- the setting up of farms where riding can be practised; arranging trails for hiking, cycling, etc. These should be marked with specific signs.

- building boutiques where the locals can sell their products, such as honey, bakery products, woven and embroidered clothes, wooden objects, etc.;

- rehabilitation of peasant households, with special emphasis on traditional architecture;

- creation of campsites with the necessary facilities;

- arranging some viewpoints; 
- arranging parking areas;

- creating a webpage by which the village can be promoted and introduced in tourism networks;

- the location of milestones to mark the delimitation of the hamlets;

- including the village into a tourist circuit (Cocean, 2014). An example of a circuit can be constituted by traversing a route through the villages of Zece Hotare and Șuncuiuș, through which to connect the tourist resources in the area (Figure 18). The route could include cycling tour through the hamlets, stopping on the route to explain the process of burning limestone, viewing handicrafts from some households, following the clay mining process, and viewing other objectives they are interested in. After one finishes the circuit through the village of Zece Hotare, he/she may ride the bike on the road DC 177 (Figure 17), which connects with the village of Șuncuiuș.

After arriving in Șuncuiuș, tourists can leave their bikes in a place arranged for bicycles, and then they can choose from various options, such as: practising speleological tourism through a tour of the caves: Izbândiş and the eruption of the same name, Ungur Mare, Vântului, Vadu Crişului (this being a landscaped cave); hiking along Crișul Repede Gorge, starting from Bratca to Vadul Crișului, where at the end of the route tourists can admire Vadul Crișului waterfall and visit the cave bearing the same name; on the same route, they can choose to go rafting; or another choice would be to make a via ferrata route. Tourists also have the option to stay at the beach on the banks of Crișul Repede River, where there is a landscaped beach. After completing the route, tourists can dine at the guesthouse restaurant in the area, and finally return to Zece Hotare by bike.
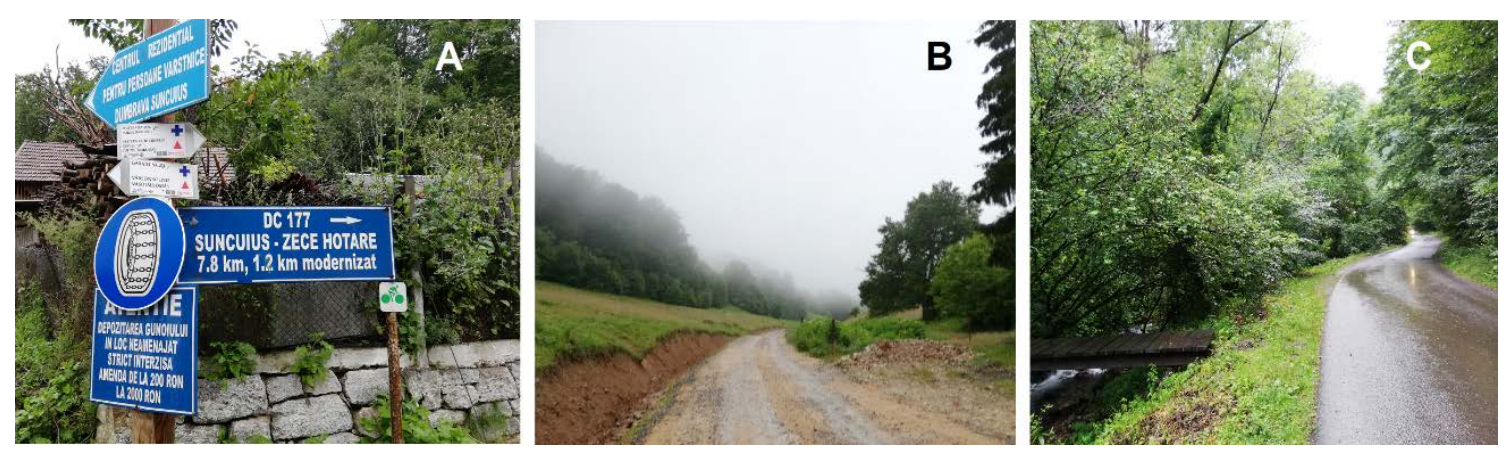

Figure 17: Sections of DC 177communal road

(A- Signs to tourist attractions; B- Old road; C- Modernized road)

Source: Alina Toderaș, 2020

The village can be included in other tourist circuits that connect the tourist objectives within it and the neighbouring ones, so the influx of tourists would increase in the nearby settlements, this contributing to their economic development.

All these proposals for improvement, in fact, represent shortcomings of the village, and their achievement would lead to its development. These must be applied in accordance with the Sustainable Rural Development Strategy of Şuncuiuş Commune, with the Management Plan of the Natura 2000 site ROSCI 0062 Crișul Repede-Pădurea Craiului Gorge, with the Tourism Strategy of Bihor County and Pădurea Craiuluisubarea. 


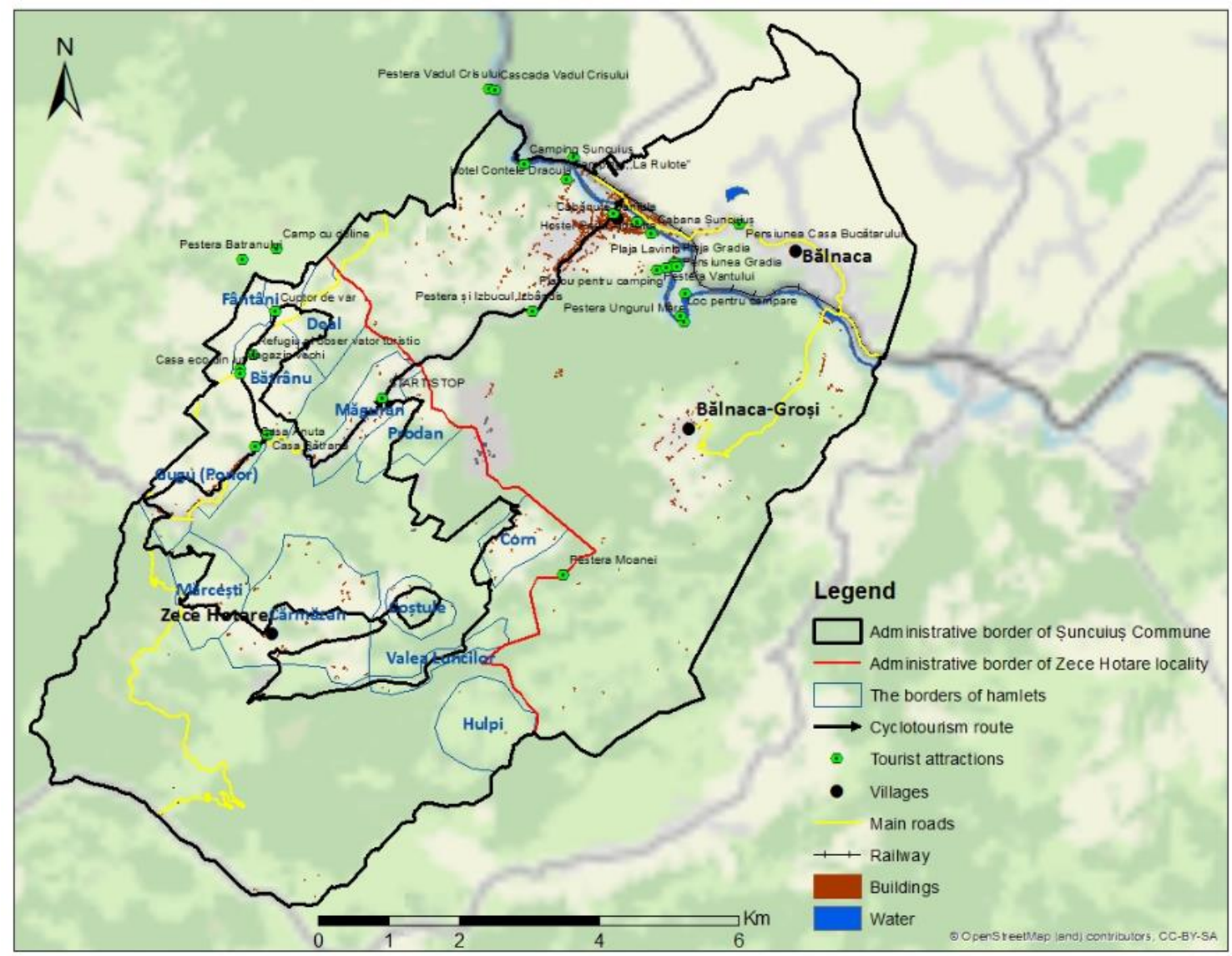

Figure 18: Cycle tourism trip and tourist attractions in the village of Șuncuiuș

Source: the author, based on vector and raster data from Geofabrik GmbH \& OpenStreetMap Contributors, 2018; data provided by the author: the borders of Zece Hotare, cycle tourism route

Before being put into practice, these proposals should be represented first by the modelling method, applying a model that can be processed using Geographic Information Systems, to see exactly what structure the village will have after setting these projects and what would be the best points for their location, because the achievement of these proposals involves a process of remodelling the geographical space of the village, taking into account certain factors, especially the geographicalones.

\section{CONCLUSIONS}

The choice of tourists to spend their holidays in places that are less polluted and crowded, such as rural areas located in the mountains, has led to the practice and development of agritourism, as well as of rural tourism. By practising these forms of tourism, tourists understand better the habits, traditions, mentality, way of life of the inhabitants of the areas they visit, thus having a broad perception of the visited places. Also, through the activities they perform in the visited places, for example the leisure activities, tourists contribute to the economic development of the villages (Antonescu \& Antonescu, 2013, p. 127). 
Among the advantages of practising rural tourism are: the capitalization of agricultural areas, natural resources, cultural heritage, village traditions, agricultural products, job creation, infrastructure improvement (Jurcanu \& Roşca, 2012, pp. 86-87). By combining agritourism and ecotourism, rural tourism is considered the most suitable for ensuring and protecting the cultural values of an area (Cocean, 2011, pp. 212-214; Ilovan \& Dulamă, 2006; Ilovan, 2012).

Following the analysis of its resources and whether the proposed arrangements will be made, I consider that Zece Hotare village can become a pole of attraction for rural tourism, even if it should compete with its neighbouring settlements, such as Șuncuiuș, which is already acknowledged for speleological tourism, because each area is unique in its landscape and the experience it offers from a tourist point of view. The tourist interest for the existing reso urces might increase, due to their complexity and variety, some being unaltered by the anthropogenic activity. In order to promote tourism in this village, Zece Hotare should be included in the tourist circuit of Șuncuiuș commune.

A factor that could temporarily hinder the practice of tourism would be the weather conditions in some periods of the seasons, especially in winter, when the snow layer can reach a thickness of 60 centimetres, which could make it difficult to access some areas of the village; although this resource could also be used, a ski slope could be set, because the large amount of snow favours practising winter sports for a long period.

The economic development of this village would have a positive impact on the entire Șuncu iuș commune, it would lead to the improvement of the living conditions of the locals and would hinder the process of ongoing migration of the inhabitants (Călina, 2008). But in order to achieve this development, it must be supported by the political, administrative, socio-cultural, economic, and ecological factors (Mureşianu, 2010).

All the above mentioned proposals must be made taking into account the promotion of sustainable development, and in accordance with Natura 2000 Site Regulation ROSCI0062 Crișului Repede - Pădurea Craiului Gorge dating back to June 28, 2016 because the whole village is a site of community importance, managed by The Center for Protected Areas and Sustainable Development Bihor - Pădurea Craiului Branch, custodians of this protected area (Regulation of the Natura 2000 site ROSCl 0062 Crișului Repede - Pădurea Craiului Gorge since June 28, 2016; Environmental opinion No. 4 of 18. 04. 2017), as well as Bihor County Sustainable Development Strategy, developed for the period 2014-2020.

Also in the process of sustainable development of the village, it must be done with a view to integration at European level. Within the European Union, agritourism and rural tourism are considered sustainable only if they are carried out in accordance with the service quality strategy (Jurcanu \& Roșca, 2012, p. 88).

The development of sustainable tourism in protected natural areas has led to the emergence of a distinct type of tourism called ecotourism. Its role is to protect natural landscapes and ecological biodiversity, in relation to what tourists who spend their holidays in such a place want. Also, by practising ecotourism, new opportunities are created for the counties to locally develop (National strategy for the development of ecotourism in Romania-context, vision, and objectives - 2019-2029).

If the institutions responsible for the development of this village on all levels would take into account the already stated measures, Zece Hotare village could be introduced in the circuit of rural tourism and agritourism at county, regional, national and even international level. 


\section{REFERENCES}

AGENTTIA NAȚIONALĂ PENTRU PROTECȚIA MEDIULUI BIHOR [BIHOR NATIONAL AGENCY FOR ENVIRONMENTAL PROTECTION] (2017). Aviz de mediu nr. 4 din 18. 04. 2017 [Environmental Opinion No. 4 from 18. 04. 2017]. Retrieved 19 June 2020, from http://apmbh.anpm.ro/documents/14457/33461147/Aviz+4+din+18+04+2017+PRIMARIA+SUNCUIUS.pdf/e 56567e1-c803-4f5e-bfbc-1dbbf2ec0aee

ANTONESCU, D. \& ANTONESCU, R.-M. (2013). Dezvoltarea durabilă a agroturismului în Uniunea Europeană și în România [Sustainable Development of Agritourism in the European Union and in Romania], 119-128. Retrieved 17 June 2020, from http://conferinta2013.academiacomerciala.ro/_VOLCONF2013PDF/volumconferinta/DEZVOLTAREA\%20DUR ABILA\%20A\%20AGROTURIMSULUI\%20IN\%20UNIUNEA\%20EUROPEANA\%20SI\%20IN\%20ROMANIA_ANTONE SCU.pdf

ASOCIATIA DE ECOTURISM DIN ROMÂNIA [ROMANIA'S ECOTOURISM ASSOCIATION] (2020). Descoperă EcoRomânia [Discover Eco-Romania]. Retrieved 17 June 2020, from https://www.eco-romania.ro/blog/11atractii-turistice-de-vazut-in-padurea-craiului/

ASOCIATIA SALVATORILOR MONTANI BIHOR [BIHOR MOUNTAIN RESCUERS ASSOCIATION] (2015). Serviciul Județean Salvamont-Salvaspeo Bihor [Salvaspeo Bihor County Mountain Rescue Service]. Retrieved 17 June 2020, from https://www.salvamontbihor.ro/page/trasee-turistice-padurea-craiului

AVRAM, D. (2015). Agrotourism in Romania - Promoting through the Representatives in the Agricultural Field. Cactus Tourism Journal, 11(1), 20-24.

BÂC, D.P. (2015). Forms of Sustainable Tourism Suitable to Apuseni Mountains, Romania. The Annals of University of Oradea, 1(1), 663-670.

BĂDULESCU, A. (2004). Economia turismului [Tourism Economy]. Oradea: Editura Universităţii din Oradea.

BARBU, I., OLAH, G., \& BARBU, S.-A. (2010). Turismul rural în Regiunea de dezvoltare Nord-Vest [Rural Tourism in the North-West Development Region]. Retrieved 17 June 2020, from https://www.researchgate.net/publication/273658872_TURISMUL_RURAL_IN_REGIUNEA_DE_DEZVOLTARE NORD-VEST

BENTE, F. \& BENTE, C. (2008). Directions of Tourism Development in the Bihor County. Geographica Timisiensis, $17(1-2), 251-256$

BRAN, F., MARIN, D., \& SIMON, T. (1997). Turismul rural: modelul European [Rural Tourism: European Model]. Bucureşti: Editura Economică.

BREJEA, R., DOMUȚA, C., BARA, V., ŞANDOR, M., BARA, C., BARA, L., SABĂU, N. C., DOMUTA, A., SAMUEL, A., BORZA, I., \& VUŞCAN, A. (2011). Researches regarding the Vegetation Reconstruction in a Former Bauxite Quarry in the Pădurea Craiului Mountain Romania. Journal of Environmental Protection and Ecology, 12(4), 1873-1882.

BREJEA, R., DOMUȚA, C., ŞANDOR, M., SAMUEL, A. D., BARA, V., CIOBANU, G., SABĂU, N. C., CIOBANU, C., BARA, C., DOMUTA, C., BARA, L., BORZA, I., GÂTEA, M., \& VUŞCAN, A. (2008). The Study of Physical, Chemical and Enzymatical Properties of the Land from a Former Bauxite Quarry in the Pădurea Craiului Mountains in the Context of Ecological Reconstruction. Carpathian Journal of Earth and Environmental Sciences, 3(2), 49-63.

CĂLINA, J. (2008). Agroturism [Agrotourism]. Craiova: Sitech.

CIANGĂ, N. (1998). Turismul rural, factor de conservare, valorificare şi dezvoltare a habitatului uman [Rural Tourism, as a Factor of Conservation, Capitalization and Development of Human Habitat]. Studia Universitatis BabeșBolyai, Geographia, XLIII(2), 131-136.

CIOLAC, R., ADAMOV, T., IANCU, T., POPESCU, G., LILE, R., RUJESCU, C., \& MARIN, D. (2019). Agrotourism-A Sustainable Development Factor for Improving the "Health" of Rural Settlements. Apuseni Mountains Area Case Study. Sustainability, 11(5), 1467, 1-24. DOI:10.3390/su11051467

CIOLAC, R., IANCU, T., BRAD, I., POPESCU, G., MARIN, D., \& ADAMOV, T. (2020). Agrotourism Activity-A "Smart Chance" for Mountain Rural Environment's Sustainability. Sustainability, 12(15), 6237, 1-25. DOI: $10.3390 /$ su12156237

CIUREA, I.-V. (2011). Strategii de dezvoltare rurală durabilă prin agroturism [Strategies for Sustainable Rural Development through Agrotourism]. laşi:TERRA NOSTRA. 
COCEAN, P. \& ILOVAN, O.-R. (2008). Elemente ale managementului dezvoltării durabile [Elements of the Management for Sustainable Development]. Geographia Napocensis, 2(2), 5-17.

COCEAN, P. (2011). "Tările". Regiuni geografice şi spaţii mentale ["Lands". Geographical Regions and Mental Spaces]. Cluj-Napoca: Presa Universitară Clujeană.

COCEAN, P. (coordinator) (2014). Strategia de dezvoltare a comunei Aiton: 2014-2050 [Development Strategy for Aiton Commune: 2014-2050]. Cluj-Napoca: Risoprint.

CONSILIUL JUDETEAN BIHOR [BIHOR COUNTY COUNCIL] (2014-2020). Strategia de dezvoltare durabilă a județului Bihor pentru perioada 2014-2020 [Sustainable Development Strategy of Bihor County for the Period 20142020]. Retrieved 19 June 2020, from

https://www.cjbihor.ro/pdf/Strategia\%20pentru\%20dezvoltarea\%20durabila\%20a\%20judetului\%20Bihor\%2 02014-2020.pdf

COPERNICUS PROGRAMME (2018). CLC 2018. Retrieved 5 June 2020, from https://land.copernicus.eu/paneuropean/corine-land-cover/clc2018? tab=download

CSŐSZ, I. (1996). Agroturism montan [Mountain Agritourism]. Timişoara: Mirton.

CSŐSZ, I. (2007). Agroturism şi turism rural [Agritourism and Rural Tourism]. Timişoara: Mirton.

DRĂGAN, M. (2007). Disfavoured Zones and Tourist Areas in the Apuseni Mountains. Romanian Review of Regional Studies, 3(2), 95-101.

DRAGOŞ, D., VALCAN, V., LASCU, A., LUCIAN, M., BALA, A., \& BOGDAN, H. Bihor în imagini [Bihor in Pictures]. Retrieved 17 June 2020, from https://www.bihorinimagini.ro/trasee-turistice-in-muntii-padurea-craiului/

EU IUBESC ROMÂNIA [I LOVE ROMANIA]. Peşteri din comuna Şuncuiuş, județul Bihor [Caves in Şuncuiuş Commune. Bihor County]. Retrieved 18 June 2020, from https://locuridinromania.ro/judetul-bihor/comuna-suncuius

GAVUROVA, B., SUHANYI, L., \& RIGELSK, M. (2020). Tourist Spending and Productivity of Economy in OECD Countries - Research on Perspectives of Sustainable Tourism. Entrepreneurship and Sustainability Issues, 8(1), 983-1000, DOI: 10.9770/jesi.2020.8.1(66)

GEOFABRIK GMBH \& OPENSTREETMAP CONTRIBUTORS (2018). OpenStreetMap for Romania. Retrieved 10 June 2020, from https://download.geofabrik.de/europe/romania.html

GHEREŞ, M. (2006). Agroturism [Agritourism]. Cluj-Napoca: Risoprint.

GLĂVAN, V. (2002). Agroturism. Ecoturism [Agritourism. Ecotourism]. Sibiu: Alma Mater.

GUVERNUL ROMÂNIEI [GOVERNMENT OF ROMANIA] (2003). Hotărâre nr. 230 din 4 martie 2003 [Decision No. 230 of March 4 2003]. Monitorul Oficial, no. 190 of 26 March 2003. Retrieved 2 September 2020, from http://legislatie.just.ro/Public/DetaliiDocument/42901

HAVADI-NAGY, K.X., JORDAN, P., ILOVAN, O.-R., ZAMETTER, T.F., CRISTEA, M., \& SEBESTYÈN, T.-T. (2015). The Sustainable Development of Less-favoured Areas: A Study of the Romanian and Austrian Experiences. Romanian Review of Regional Studies, 11(2), 19-30.

IANC, C., OROŞ, B., \& MICULA, A. (2020) Travel Guide Romania. Retrieved 17 June 2020, from https://www.travelguideromania.com/ro/destinatia-ecoturistica-padurea-craiului/

ILOVAN, O.-R. \& DULAMĂ, M.E. (2006). Exploatarea potenţialului turistic al Munţilor Rodnei [Valorising the Tourist Potential of the Rodnei Mountains]. In La un pas de integrare: oportunităţi şi ameninţări [One Step to EU Integration: Opportunities and Challenges], vol. I (pp. 63-68). Craiova: Editura Universitaria.

ILOVAN, O.-R. (2005). Rodna and the Implications of the Disfavoured Zone Status. Forum Geografic, 4(4), 152-161.

ILOVAN, O.-R. (2006). Contemporary Social and Economic Coordinates of the Disadvantaged Areas of Baia Mare, Borşa-Vişeu, and Rodna. Romanian Review of Regional Studies, 1, 95-112.

ILOVAN, O.-R. (2009). Valorificarea turistică a patrimoniului construit din Mărginimea Sibiului, România [Touristic Valorising of the Built Heritage in Mărginimea Sibiului, Romania]. In Materialele Simpozionului Jubiliar Internaţional "Mediul şi dezvoltarea durabilă" [Proceedings of the International Conference "The Environment and Sustainable Development"] 70 ani de la fondarea Facultăţii Geografie, UST (pp. 211-216). Chişinău: Labirint.

ILOVAN, O.-R. (2012). Relevanţa turismului regiunii năsăudene în cadrul judeţului Bistriţa-Năsăud, România [The Relevance of Tourism in Năsăud Region within Bistriţa-Năsăud County, Romania], Economie, 31, 372-382. Retrieved 19 June 2020, from https://ibn.idsi.md/sites/default/files/imag_file/372-382.pdf 
MATIKU, S., M., ZUWARIMWE, J., \& TSHIPALA, N. (2020). Sustainable Tourism Planning and Management for Sustainable Livelihoods. Journal Development Southern Africa, 1-15, https://doi.org/10.1080/0376835X.2020.1801386

MIHUT, C. \& SZILAGYI, G. (2017). Şuncuiuş / Peşteri, castele şi trasee turistice [Şuncuiuş | Caves, Castles, and Touristic Routes]. Retrieved 18 June 2020, from https://www.digi24.ro/regional/digi24-oradea/suncuiuspesteri-castele-si-trasee-turistice-687255

MINISTERUL MEDIULUI, APELOR ŞI PĂDURILOR [MINISTRY OF ENVIRONMENT, WATER AND FORESTS] (2015). Date GIS [GIS Data]. Posted on 17 February 2015. Retrieved 2 June 2020, from http://www.mmediu.ro/articol/date-gis/434

MITRACHE, S., MANOLE, V., STOIAN, M., BRAN, F., \& ISTRATE, I. (1996). Agroturism şi turism rural [Agritourism and Rural Tourism]. Bucureşti: Fax Press.

MOISA, C. (2006). Direcţii strategice de dezvoltare a turismului în Munţii Apuseni [Strategic Directions for Tourism Development in Apuseni Mountains]. Retrieved 17 June 2020, from

https://www.researchgate.net/publication/260956325_Directii_strategice_de_dezvoltare_a_turismului_in_ Muntii_Apuseni

MORAR, C. (2013). Turism şi dezvoltare regională durabilă în zonele miniere defavorizate din judeţul Bihor [Touris m and Sustainable Regional Development in Disadvantaged Mining Areas in Bihor County]. Oradea: Editura Universităţii din Oradea.

Munții Apuseni [Apuseni Mountains]. Retrieved 2 September 2020, from https://ro.wikipedia.org/wiki/Mun\%C8\%9Bii_Apuseni

MUREŞIANU, M. (2010). Turismul rural şi dezvoltarea durabilă a satului românesc contemporan [Rural tourism and sustainable development of the contemporary Romanian village]. Cluj-Napoca: Napoca Star.

NISTOREANU, P. (2003). Ecoturism şi turism rural, ediţia a II-a, revăzută şi adăugită [Ecotourism and Rural Tourism, 2nd Reviewed Edition]. Bucureşti: ASE

PASTOR, I. (2006). Managementul turismului rural, agroturismului şi ecoturismului [Management of Rural Touris m, Agritourism and Ecotourism]. Cluj-Napoca: Risoprint.

PETREA, R. \& PETREA, D. (2001). Turism rural, ediţia a II-a, revizuită [Rural Tourism, 2nd Reviewed Edition]. ClujNapoca: Presa Universitară Clujeană.

POPA, I. (2014). Monografia satului Zece Hotare [Monograph of Zece Hotare Village]. Retrieved 19 June 2020, from https://zecehotare.wordpress.com/

Programul național de dezvoltare rurală pentru perioada 2014 - 2020 [National Rural Development Program for the Period 2014 - 2020]. Retrieved 17 June 2020, from https://www.madr.ro/docs/dezvoltarerurala/2020/PNDR-2014-2020-versiunea-X-aprobata-04.05.2020.pdf

RĂCĂŞAN, B.-S. (2018). Turismul în spaţiul rural-montan şi de contact marginal din judeţul Cluj [Tourism in the Mountainous Rural Area and of Marginal Contact in Cluj County]. Cluj-Napoca: Risoprint.

Regulamentul Sitului Natura 2000 Rosci0062 Defileul Crișului Repede - Pădurea Craiului, din 28.06.2016 [Natura 2000 Site Regulations Rosci0062 Crișului Repede - Pădurea Craiului Gorge Since June 28, 2016]. Retrieved 19 June 2020, from

https://lege5.ro/Gratuit/gezdqnrugmyq/reglementarea-activitatilor-desfasurate-pe-teritoriul-rosci0062regulament?dp=geydimrzgm2tgny

ROTURISM [ROTOURISM]. (2015-2016). ROturism magia călătoriilor [ROtourism The Magic of Travel]. Retrieved 18 June 2020, from http://www.roturism-info.ro/orase/judetul-bihor/obiective-turistice-suncuius.html

RUSU, T., MORARU, P., \& CACOVEAN, H. (2011). Dezvoltare rurală [Rural Development]. Cluj-Napoca: Risoprint.

SGROI, F. (2020). Forest Resources and Sustainable Tourism, a Combination for the Resilience of the Landscape and Development of Mountain Areas. Science of The Total Environment, 736, 1-5, https://doi.org/10.1016/j.scitotenv.2020.139539

SINERGISE LABORATORYFOR GEOGRAPHICAL INFORMATION SYSTEMS, LTD. EO Browser. The following da ta were taken: UV Aerosol Index, Carbon Monoxide (CO), Nitrogen Dioxide $\left(\mathrm{NO}_{2}\right)$, Ground-level Ozone $\left(\mathrm{O}_{3}\right)$. Retrieved 15 July 2020, from https://apps.sentinel-hub.com/eobrowser/?zoom=10\&lat=41.9\&lng=12.5\&themeld=DEFAULT-THEME 
STĂNCIULESCU, G., LUPU, N., ȚIGU, G., ȚIṬAN, E., \& STĂNCIOIU, F. (2002). Lexicon de termeni turistici [Lexicon of Touristic Terms]. Bucureşti: Oscar Print.

Strategia de dezvoltare rurală durabilă a Comunei Şuncuiuş [Sustainable Rural Development Strategy of Şuncuiuş Commune]. Retrieved 22 June 2020, from http://suncuiusbihor.ro/file_upload/Strategie\%20de\%20dezvoltare\%20durabila.pdf

Strategia naţională de dezvoltare a ecoturismului în România - context, viziune și obiective - 2019-2029 [National Strategy for Ecotourism Development in Romania - Context, Vision and Objectives - 2019-2029]. Retrieved 19 June 2020, from https://sgg.gov.ro/new/wp-content/uploads/2019/05/ANEXA-21.pdf

SURD, V. \& TURNOCK, D. (2000). Romania's Apuseni Mountains: Safeguarding a Cultural Heritage. GeoJournal, 50(23), 285-304.

TĂTAR, C.-F. (2009). Posibilități de valorificare a resurselor turistice din bazinul hidrografic Crișul Negru [Possibilities for Capitalizing the Tourist Resources from Crişul Negru Hydrographic Basin]. Oradea: Editura Universității din Oradea.

JURCANU, R. \& ROŞCA, C. (2012). Turismul rural - domeniu important al relaţiilor economice internaţionale [Rural Tourism - Important Field of International Economic Relations]. Relaţii internaţionale. Plus, 1, 85-95.

TURISM ALEȘD [ALEȘD TOURISM]. Defileul Crişului Repede (zona Şuncuiuş - Vadu Crişului) şi platoul Zece Hotare [Crişului Repede Gorge (Şuncuiuş - Vadu Crişului Area) and Zece Hotare Upland]. Retrieved 18 June 2020, from http://turismalesd.ro/defileul-crisului-repede-zona-suncuius-vadu-crisului-si-platoul-zece-hotare/

UNITED STATES GEOLOGICAL SURVEY (USGS). Earth Explorer. Retrieved 10 June 2020, from https://earthexplorer.usgs.gov/

VĂETIŞI, S. (2006). Rural Tourism in the Apuseni Mountains, Romania. An Anthropological Research on Using Natural and Cultural Resources in Developing Tourism in a Poor Region. In Babu, P.G. \& Devesh, N. (eds.), Tourists and Tourism (pp. 40-52). New Delhi: Abhijeet Publications.

VASILE, V. (2015). Editorial: Turismul rural - cheia dezvoltării turismului românesc [Editorial: Rural Tourism - The Key to the Development of the Romanian Tourism]. România Rurală, Rețeaua Națională de Dezvoltare Rurală, 24, II. Retrieved 17 June 2020, from http://madr.ro/docs/dezvoltare-rurala/rndr/RR24.pdf

WORLD BANK (2016). Romania Local Human Development Index. Created on 22 December 2016. Updated on 14 July 2017. Retrieved 5 June 2020, from https://www.arcgis.com/home/item.html?id=c0cfacee49ca4db89c175e8684ba6ecf

WORLD BANK (2017). Romania Four Degrees of Economic Potential. Created on 13 February 2017. Updated on 14 July 2017. Retrieved 5 June 2020, from https://www.arcgis.com/home/item.html?id=11f5a50eef2e4b67829f1997454d2b61

WORLD TOURISM ORGANIZATION (2004). Sustainable Tourism. Retrieved 17 June 2020, from https://sustainabletourism.net/sustainable-tourism/definitions/

ZAHARIA, C., ZAHARIA, I. \& TUDORESCU, N. (2005). Considerații privind resursele agromontanologice ale mediului înconjurător pentru dezvoltarea agroturismului în România [Considerations Regarding the Agromontanological Resources of the Environment for the Development of Agrotourism in Romania]. Analele Universităţii din Oradea, Ştiinţe Economice, XIV, 188-191. Retrieved 18 June 2020, from http://steconomiceuoradea.ro/anale/volume/tom_xiv_2005.pdf

ZHANG, Y., XIAO, X., CAO, R., ZHENG, C., GUO, Y., GONG, W., \& WEI, Z. (2020). How Important Is Community Participation to Eco-Environmental Conservation in Protected Areas? From the Perspective of Predicting Locals' Pro-Environmental Behaviours. Science of The Total Environment, 739, 139889, 1-10. 